\title{
A boundary exchange influence on deglacial neodymium isotope records from the deep western Indian Ocean
}

\author{
David J. Wilson *, \\ Alexander M. Piotrowski, \\ Albert Galy, \\ I. Nicholas McCave
}

Godwin Laboratory for Palaeoclimate Research, Department of Earth Sciences, University of Cambridge, Cambridge, CB2 3EQ, United Kingdom

* Corresponding Author (email: david.wilson@esc.cam.ac.uk)

Revised for Earth and Planetary Science Letters

$10^{\text {th }}$ May 2012 


\begin{abstract}
The use of neodymium $(\mathrm{Nd})$ isotopes to reconstruct past water mass mixing relies upon the quasi-conservative behaviour of this tracer, whereas recent studies in the modern oceans have suggested that boundary exchange, involving the addition of $\mathrm{Nd}$ from ocean margin sediments, may be an important process in the $\mathrm{Nd}$ cycle. Here we suggest that the relative importance of water mass advection versus boundary exchange can be assessed where the deep western boundary current in the Indian Ocean flows past the Madagascan continental margin; a potential source of highly unradiogenic Nd. Foraminiferal coatings and bulk sediment reductive leachates are used to reconstruct bottom water $\mathrm{Nd}$ isotopic composition $\left(\varepsilon_{\mathrm{Nd}}\right)$ in 8 Holocene age coretops, with excellent agreement between the two methods. These data record spatial variability of $\sim 4 \varepsilon_{\mathrm{Nd}}$ units along the flow path of Circumpolar Deep Water; $\varepsilon_{\mathrm{Nd}} \approx-8.8$ in the deep southern inflow upstream of Madagascar, which evolves towards $\varepsilon_{\mathrm{Nd}} \approx-$ 11.5 offshore northern Madagascar, whereas $\varepsilon_{\mathrm{Nd}} \approx-7.3$ where deep water re-circulates in the eastern Mascarene Basin. This variability is attributed to boundary exchange and, together with measurements of detrital sediment $\varepsilon_{\mathrm{Nd}}$, an isotope mass balance suggests a deep water residence time for $\mathrm{Nd}$ of $\leq 400$ years along the Madagascan margin. Considering deglacial changes, a core in the deep inflow upstream of Madagascar records $\varepsilon_{\mathrm{Nd}}$ changes that agree with previous reconstructions of the Circumpolar Deep Water composition in the Southern Ocean, consistent with a control by water mass advection and perhaps indicating a longer residence time for $\mathrm{Nd}$ in the open ocean away from local sediment inputs. In contrast, sites along the Madagascan margin record offset $\varepsilon_{\mathrm{Nd}}$ values and reduced glacial-interglacial variability, underlining the importance of detecting boundary exchange before inferring water mass source changes from $\mathrm{Nd}$ isotope records. The extent of Madagascan boundary exchange appears to be unchanged between the Holocene and Late Glacial periods, while a consistent shift towards more radiogenic $\varepsilon_{\mathrm{Nd}}$ values at all sites in the Late Glacial compared to the Holocene may represent a muted signal of a change in water mass source or composition.
\end{abstract}

\title{
Key words
}

Indian Ocean, Circumpolar Deep Water, neodymium isotopes, ocean circulation, boundary exchange, deglaciation

\section{Highlights}

$>$ Boundary exchange affects bottom water $\varepsilon_{\mathrm{Nd}}$ along Madagascar and Mascarene margins.

$>$ Sediment derived from ancient shield rocks can contribute to boundary exchange.

$>$ Holocene spatial variability of $4 \varepsilon_{\mathrm{Nd}}$ implies local $\mathrm{Nd}$ residence time $\leq 400$ years.

$>$ Need to consider boundary exchange when interpreting $\mathrm{Nd}$ isotope records.

$>$ Madagascan boundary exchange is constant between Late Glacial and Holocene. 


\section{Introduction}

The earliest studies on the $\mathrm{Nd}$ isotopic composition of ferromanganese crusts, nodules and seawater demonstrated distinct provinciality between Atlantic Ocean and Pacific Ocean basins, with the implication that $\mathrm{Nd}$ isotopes could be used to trace water mass sourcing and mixing in both the present and past oceans (O'Nions et al., 1978; Piepgras et al., 1979; Piepgras and Wasserburg, 1980). The Nd isotopic composition of the Southern Ocean can be explained as a mixture of Atlantic and Pacific waters (Piepgras and Wasserburg, 1982), while depth profiles of seawater $\mathrm{Nd}$ isotopes in the Atlantic Ocean match the water mass structure inferred from conservative tracers such as salinity (von Blanckenburg, 1999). This has led to a view of $\mathrm{Nd}$ isotopes as a quasi-conservative tracer with potentially great value to paleoceanographers (e.g. Frank, 2002; Goldstein and Hemming, 2003). In such a view, the Nd isotopic composition of a water mass is acquired through continental weathering in its source region, generating distinct compositions for North Atlantic Deep Water (NADW; $\varepsilon_{\mathrm{Nd}}=-13$ to -14) and Pacific waters $\left(\varepsilon_{\mathrm{Nd}}=-4\right.$ to -5$)$. The $\varepsilon_{\mathrm{Nd}}$ notation refers to the deviation in parts per 10,000 from the present day composition of the Chondritic Uniform Reservoir $\left({ }^{143} \mathrm{Nd} /{ }^{144} \mathrm{Nd}=\right.$ 0.512638; Jacobsen and Wasserburg, 1980; Wasserburg et al., 1981). The mean deep ocean residence time of $\mathrm{Nd}$ is proposed to be $\sim 200-1000$ years (Tachikawa et al., 1999; Tachikawa et al., 2003; Siddall et al., 2008), comparable to the mixing time of the deep ocean ( 1500 yrs; Broecker and Peng, 1982), so that the Nd isotopic composition of deep water is expected to be controlled predominantly by mixing between water masses (Goldstein and Hemming, 2003).

A series of studies over the past decade have therefore exploited $\mathrm{Nd}$ isotopes as a paleoceanographic tool to investigate glacial-interglacial and millennial timescale changes in water mass structure and sourcing, particularly in the Atlantic Ocean (e.g. Rutberg et al., 2000; Piotrowski et al., 2005; Gutjahr et al., 2008; Pahnke et al., 2008; Roberts et al., 2010). If $\varepsilon_{\mathrm{Nd}}$ is treated as a conservative tracer, comparison with non-conservative tracers may also be valuable; for example, its coupling or decoupling with carbon isotope changes through time may provide evidence on productivity, nutrient regeneration or other carbon cycle changes (e.g. Piotrowski et al., 2005; Piotrowski et al., 2008; Piotrowski et al., 2009).

Whereas the use of $\mathrm{Nd}$ isotopes to reconstruct past water mass mixing relies upon quasiconservative tracer behaviour (Goldstein and Hemming, 2003), recent studies in the modern oceans have suggested that 'boundary exchange', involving the addition of $\mathrm{Nd}$ from ocean margin sediments, may be an important process that contributes to non-conservative behaviour (e.g. Lacan and Jeandel, 2005 and references therein). However, modelling studies at a global scale have reached different conclusions on the relative importance of water mass advection and boundary exchange as controls on the $\mathrm{Nd}$ isotopic distribution of seawater (Arsouze et al., 2007; Jones et al., 2008; Siddall et al., 2008; Arsouze et al., 2009; Rempfer et al., 2011). Uncertainty in the models is due to (i) the strong sensitivity of models to poorly constrained boundary conditions (surface inputs, scavenging, boundary exchange); (ii) a lack of understanding of the mechanism for boundary exchange; and (iii) an inherent difficulty in distinguishing between the controls on a global scale because the detrital $\mathrm{Nd}$ isotopic 
composition of the boundaries (Jeandel et al., 2007) generally changes along the deep water flow path in a similar manner to that expected for Atlantic-Pacific water mass mixing.

We suggest that observations at a higher spatial resolution are required to test the importance of boundary exchange and that the deep western Indian Ocean is a sensitive region for this. This is because its deep western boundary current, which originates as Circumpolar Deep Water (CDW) in the Southern Ocean, flows past the Madagascar and Mascarene margins which have distinct Nd isotopic compositions. Additionally, Madagascar is dominantly granitic and the Mascarene Plateau is partly basaltic, potentially allowing us to assess the possibility for boundary exchange from different lithologies. For the Indian Ocean there is a general paucity of seawater $\varepsilon_{\mathrm{Nd}}$ measurements (particularly for deep water), but limited measurements exist from the Madagascar, Mascarene and Somali Basins (Bertram and Elderfield, 1993). More extensive seawater Nd isotope data (e.g. GEOTRACES) are likely to help determine the importance of boundary exchange in the modern oceans, but at present this is lacking and we instead suggest that reconstructions from authigenic phases in the sediment should also provide such evidence (see, for example, Horikawa et al., 2011). Our records of past changes are obtained from sediment cores, and not seawater, and therefore this approach has the further benefit that observations from coretop authigenic sediments may then be directly applied to interpret downcore changes.

Therefore there are three specific aims of this study: (i) to determine the balance between water mass advection and boundary exchange as controls on the Holocene $\varepsilon_{\mathrm{Nd}}$ composition of the deep western Indian Ocean; (ii) to evaluate how boundary exchange has changed between the Late Glacial and Holocene periods; and (iii) to consider the implications of boundary exchange for the paleoceanographic interpretation of deglacial $\mathrm{Nd}$ isotope records. Together, these provide evidence on the importance and spatial extent of the boundary exchange process for $\mathrm{Nd}$ isotopes, with implications for future paleoceanographic and modelling studies.

\section{Regional setting and hydrography}

The deep Indian Ocean is ventilated at depth from the south by CDW; a well-mixed water mass which originates in the Southern Ocean where its $\varepsilon_{\mathrm{Nd}}$ composition is homogeneous at around $-8.6 \pm 0.4(2 \sigma)$ (Stichel et al., 2012). The total deep inflow to the Indian Basin is estimated at $11 \pm 4$ Sverdrups (Ganachaud et al., 2000), which comprises northward flowing CDW that is restricted by ridges and plateaus to a western and a central branch (You, 2000; Schott and McCreary, 2001). The circulation in the deep western boundary current is described in a number of studies (e.g. Mantyla and Reid, 1995; You, 2000; Schott and McCreary, 2001; Donohue and Toole, 2003; McCave et al., 2005). CDW flows northwards through the Crozet Basin and enters the Madagascar Basin through fracture zones in the Southwest Indian Ridge at around $30{ }^{\circ} \mathrm{S}, 60^{\circ} \mathrm{E}$ (Figure 1) where maximum sill depths are $~ 3.9 \mathrm{~km}$. It flows westwards and then northwards as a deep western boundary current along the Madagascan margin in the Mascarene Basin, and then through Amirante 
Passage into the Somali and Arabian Basins (Figure 1). Towards the northern end of the Mascarene Basin, the shallower levels of northward-flowing CDW meet with southwardflowing North Indian Deep Water (NIDW) (Johnson et al., 1998), a re-circulated branch of CDW which is chemically similar but enriched in nutrients (You, 2000). The two water masses compete and water re-circulates clockwise within the Mascarene Basin (Figure 1). Although the hydrographic properties describe the mean flow well, the actual motion in the Mascarene Basin and along the Madagascan margin, as measured by current meters, is dominated by an oscillating flow with amplitude $\sim 10 \mathrm{~cm} / \mathrm{s}$ and period $\sim 60$ days due to Rossby waves (Warren et al., 2002). Concerning the Rossby wave motion, these authors remark that "...its occurrence is a great disappointment because it obliterates a portion of the mean flow that the current-meter array was put out to measure", i.e. the northward mean flow is weak.

The deep boundary current flows past Madagascar, which is dominated by old continental crustal rocks and is expected to represent an unradiogenic Nd source. Paquette et al. (1994) reported $\varepsilon_{\mathrm{Nd}}=-28.2 \pm 8.0(2 \sigma, \mathrm{n}=6)$ for southeast Madagascan granulites and Kroner et al. (2000) reported $\varepsilon_{\mathrm{Nd}}=-22.1 \pm 8.0(2 \sigma, \mathrm{n}=7)$ for central Madagascan granitoidgneisses. Cretaceous basalts also occur along the southeast Madagascan coast, with instead more radiogenic isotopic compositions of $\varepsilon_{\mathrm{Nd}}=+4.6 \pm 3.0(2 \sigma, \mathrm{n}=3)$ (Mahoney et al., 1991). The geology of the Mascarene Plateau is varied and $\mathrm{Nd}$ isotope measurements are available from southern Mascarene Plateau volcanics with $\varepsilon_{\mathrm{Nd}}=+6.3 \pm 1.6(2 \sigma, \mathrm{n}=8)$ (White et al., 1990) and Reunion Island volcanics with $\varepsilon_{\mathrm{Nd}}=+3.1-4.5$ (Bosch et al., 2008). In the global compilation of Jeandel et al. (2007), the margin of the western Indian Ocean in this region is assigned a value of $\varepsilon_{\mathrm{Nd}}=-14$, but this clearly represents an average of old continental crustal sources and younger volcanics rather than a uniform source of this composition.

For this study, eight cores in the Madagascar and Mascarene Basins were selected from the suite of WIND cores recovered on the R.R.S. Charles Darwin Cruise 129 in 2001 (Table 1, Figure 1; McCave, 2001). Sedimentation rates are generally rather low $(<4 \mathrm{~cm} / \mathrm{kyr})$ and south of Madagascar much less $(<1 \mathrm{~cm} / \mathrm{kyr}$ ), with winnowing in places (McCave et al., 2005). The cores are from a restricted range of water depths $(3.7-4.2 \mathrm{~km})$ within CDW, with the exception of WIND 10B $(2.9 \mathrm{~km})$ at a slightly shallower level within CDW. Salinity (S) decreases slightly with depth, reflecting a decreasing NADW component in the CDW, and an approximate boundary between Upper CDW (S > 34.72) and Lower CDW (S < 34.72) at around $4 \mathrm{~km}$ has been described (e.g. McCave et al., 2005). The salinity difference between the deepest (WIND 12B) and the shallowest (WIND 10B) cores of our study is $\sim 0.02$ salinity units (Bertram and Elderfield, 1993), suggesting that with conservative water mass mixing they should differ in $\mathrm{Nd}$ isotopes by no more than $0.3 \varepsilon_{\mathrm{Nd}}$ units (see Goldstein and Hemming, 2003; their Figure 12). In the discussion that follows, this minor difference is neglected and we consider all the cores to lie within essentially the same water mass. 


\section{Materials and methods}

Coretop sediments (0-2 $\mathrm{cm}$ core depth) were sampled from eight WIND box cores (suffix 'B') preserving good core tops with Holocene radiocarbon ages (Figure 1, Table 1). For five of these sites, glacial sediment was sampled from the accompanying longer kasten cores (suffix ' $\mathrm{K}$ '). Given the relatively low sedimentation rates, it was not possible to specifically distinguish the Last Glacial Maximum in all five kasten cores and we therefore targeted the Late Glacial period (corresponding approximately to Marine Isotope Stage 2), with the expectation from the deep South Atlantic Cape Basin $\varepsilon_{\mathrm{Nd}}$ record (Piotrowski et al., 2005) that $\mathrm{CDW} \varepsilon_{\mathrm{Nd}}$ should not have varied much within this time window. The Late Glacial period in WIND $5 \mathrm{~K}, 10 \mathrm{~K}$ and $28 \mathrm{~K}$ was identified using benthic $\delta^{18} \mathrm{O}$ records (McCave et al., 2005), while for WIND $12 \mathrm{~K}$ and $24 \mathrm{~K}$ we used correlation of their magnetic susceptibility records to that from WIND 28K (see Figure S1 in Supplementary information). For WIND $28 \mathrm{~K}$, with a sedimentation rate of $4-5 \mathrm{~cm} / \mathrm{kyr}$, the deglacial period was sampled at $\sim 4 \mathrm{~cm}(\sim 1$ kyr) resolution, with age control provided by ten radiocarbon dates from 8-30 ka BP (Kiefer et al., 2006; Yu et al., 2010).

In order to reconstruct bottom water $\varepsilon_{\mathrm{Nd}}$ compositions we used acid-reductive leaching of bulk sediment, which aims to extract $\mathrm{Nd}$ from the hydrogenetic ferromanganese oxyhydroxide coatings on detrital and biogenic grains (Chester and Hughes, 1967; Rutberg et al., 2000; Bayon et al., 2002; Gutjahr et al., 2007; Martin et al., 2010). Briefly, bulk sediment samples of $5-10 \mathrm{~cm}^{3}$ volume were leached in $30 \mathrm{~mL} 0.44 \mathrm{M}$ acetic acid solution (buffered to pH 5 by sodium acetate) in $50 \mathrm{~mL}$ centrifuge tubes on a rotating wheel at room temperature. This was repeated 13 times over 28 days until carbonate had been removed from all samples. Samples were washed at least twice with de-ionised water, before the ferromanganese oxides were recovered by acid-reductive leaching for 1 hour in $30 \mathrm{~mL}$ of a $\mathrm{pH} 2$ solution of $0.02 \mathrm{M}$ hydroxylamine hydrochloride $(\mathrm{HH})$ in $4.4 \mathrm{M}$ acetic acid, in $50 \mathrm{~mL}$ centrifuge tubes on a rotating wheel at room temperature. This 'HH leachate' was centrifuged at $5000 \mathrm{rpm}$ and decanted three times in sequence to prevent the transfer of detrital particles, before chemical separation and mass spectrometry. For some samples, we also carried out a single step acidreductive leach, which followed the method described above for $\mathrm{HH}$ leachates but with the decarbonation step removed (i.e. 'non-decarbonated HH leachates').

We also used 'uncleaned' foraminifera (cleaned of detritus but not chemically cleaned) as a different substrate for reconstructing bottom water $\varepsilon_{\mathrm{Nd}}$ compositions, following Roberts et al. (2010) and Elmore et al. (2011), after Palmer and Elderfield (1985). Briefly, bulk sediment samples were wet sieved ( $>3 \mu \mathrm{m}$ ) and mixed species of planktonic foraminifera were picked from the $>355 \mu \mathrm{m}$ fraction to give sample sizes of 30-100 $\mathrm{mg}$. The foraminifera were crushed between glass plates and fine clays and detrital silicates were removed by repeated sonication and pipetting until the water remained clear. The samples were examined under a microscope and, where necessary, any remaining detrital grains were removed with a fine brush, although the detrital content of all samples was negligible. After washing with de-ionised water, 0.5 
$\mathrm{mL}$ of de-ionised water was added followed by up to $1 \mathrm{~mL}$ of $1 \mathrm{M}$ acetic acid over a period of a few hours until the crushed foraminifera fragments had dissolved.

Characterisation of the detrital sediment followed Bayon et al. (2002). After decarbonation and $\mathrm{HH}$ leaching of bulk sediments, a further two day leach (0.02 M hydroxylamine hydrochloride-4.4 $\mathrm{M}$ acetic acid) was used to remove any remaining ferromanganese oxides, since the first $\mathrm{HH}$ leaching step does not quantitatively remove all the oxides (Bayon et al., 2002; Gutjahr et al., 2007). The residue (considered to represent the detrital component) was dried, ground using a pestle and mortar and oven roasted in a platinum crucible at $500^{\circ} \mathrm{C}$ for 5 hours. It was homogenised and $\sim 30 \mathrm{mg}$ was weighed and dissolved in a Savillex vial at $110^{\circ} \mathrm{C}$ for $\sim 48$ hours using a mixture of concentrated $\mathrm{HCl}$ (1 $\mathrm{mL})$ and $\mathrm{HF}(0.5 \mathrm{~mL})$. After drying down, it was re-dissolved in aqua regia, a mixture of concentrated $\mathrm{HNO}_{3}(0.67 \mathrm{~mL})$ and $\mathrm{HCl}(0.33 \mathrm{~mL})$, at $80^{\circ} \mathrm{C}$ for $\sim 24$ hours, and dried down again.

For all samples, the rare earth element fraction was separated using Eichrom TRUspec $^{\mathrm{TM}}$ resin (100-150 $\mu \mathrm{m}$ mesh) in $100 \mu \mathrm{l}$ Teflon columns, and the $\mathrm{Nd}$ fraction was isolated using Eichrom LNspec ${ }^{\mathrm{TM}}$ resin $(50-100 \mu \mathrm{m}$ mesh) on volumetrically calibrated Teflon columns. The Nd isotopic composition was analysed on the Nu Plasma multi-collector inductively-coupled plasma mass spectrometer (MC-ICP-MS) in the Department of Earth Sciences at the University of Cambridge, using an exponential mass fractionation correction (to ${ }^{146} \mathrm{Nd} /{ }^{144} \mathrm{Nd}=0.7219$ ) and standard-sample bracketing with concentration-matched JNdi-1 neodymium isotope standard (Tanaka et al., 2000).

\section{Results and discussion}

The Nd isotopic composition of authigenic and detrital phases is reported in Table 2 for the Holocene coretop transect and in Table 3 for the Late Glacial transect and the deglacial period in core WIND 28K. A selection of the data are plotted on maps in Figure 2 and all Holocene and Late Glacial data are plotted graphically versus distance along the CDW flow path in Figure 3. The deglacial Nd isotope data from WIND 28K are plotted in Figure 4.

\subsection{Characterisation of the detrital sediment $\varepsilon_{\mathrm{Nd}}$}

The highly unradiogenic $\varepsilon_{\mathrm{Nd}}$ of the detrital sediment (Figure 2a) supports a dominant source from Madagascar. This is clearly seen at WIND 12B and 24B along the Madagascan margin, but also at WIND 10B in advance of the margin and at WIND 28B beyond the margin (Figure 2a). This distribution pattern may be explained by deep flow reversals of 60 day period in this Rossby wave-dominated regime (Warren et al., 2002), since just 30 days of 'reversed' (i.e. southward) flow will transport sediment over $100 \mathrm{~km}$. The most unradiogenic detrital sediment $\varepsilon_{\mathrm{Nd}}$ is observed at WIND 10B and 12B ( -18.2) near southeast Madagascar (Figure 2a), which is consistent with an old Madagascan source but is not as unradiogenic as observed in the Paquette et al. (1994) study. The limited measurements on Madagascan rocks 
may be insufficient to fully characterise the Madagascan sediment inputs to the ocean, and our measurements may provide a better estimate of the integrated input. Alternatively, these values could be more radiogenic due to mineralogical and/or grain size sorting (McLennan et al., 1990) or mixing with a minor but widely-dispersed volcanic component.

Northwards from WIND 12B, the detrital sediment $\varepsilon_{\mathrm{Nd}}$ values increase to -15.4 at WIND 24B and -14.2 at WIND 28B (Figure 2a), which may reflect inputs from central Madagascar (Kroner et al., 2000) that are more radiogenic than those from southeast Madagascar (Paquette et al., 1994), but more likely records the southward transport of sediments from the basaltic Farquhar Ridge (northeast of Madagascar) during Rossby wavedriven flow reversals. The most northerly core WIND 30B $\left(\varepsilon_{\mathrm{Nd}}=-12.1\right)$ is presumably more strongly influenced by such Farquhar Ridge sediments, while cores WIND 32B $\left(\varepsilon_{\mathrm{Nd}}=-9.8\right)$ and WIND 35B $\left(\varepsilon_{\mathrm{Nd}}=-9.4\right)$ on the eastern side of the Mascarene Basin are presumably influenced by volcanic rocks of the Mascarene Plateau and/or Reunion. Nevertheless, the relatively unradiogenic $\varepsilon_{\mathrm{Nd}}$ values suggest that a significant Madagascan continental component remains part of the sediment mixture at WIND 30-35B.

\subsection{Reliability of bottom water $\varepsilon_{\mathrm{Nd}}$ reconstructions}

Acid-reductive $\mathrm{HH}$ leachates of bulk decarbonated sediments are expected to record a bottom water $\varepsilon_{\mathrm{Nd}}$ composition (e.g. Bayon et al., 2002; Gutjahr et al., 2007; Martin et al., 2010), but may not reliably recover bottom water compositions in all locations. This has been variously attributed to the presence of continental 'preformed' ferromanganese oxides (Bayon et al., 2004; Bayon et al., 2009), the downslope transport of authigenic ferromanganese oxides (Gutjahr et al., 2008; Stumpf et al., 2010), or the laboratory leaching of detrital volcanic material (Vance et al., 2004; Roberts et al., 2010; Elmore et al., 2011). Therefore, we additionally measured the $\varepsilon_{\mathrm{Nd}}$ composition of uncleaned planktonic foraminifera, which have been cleaned of detritus but not chemically cleaned; in this case, given the low $\mathrm{Nd}$ concentration in biogenic calcite, a mass balance dictates that their $\varepsilon_{\mathrm{Nd}}$ composition should be dominated by authigenic ferromanganese oxide coatings derived from bottom water (Palmer, 1985; Palmer and Elderfield, 1986; Pomies et al., 2002; Roberts et al., 2010). By physically separating the foraminifera from the detrital components in the sediment, this method should be insensitive to the detrital contamination that could potentially affect $\mathrm{HH}$ leachates of bulk decarbonated sediments (e.g. Elmore et al., 2011). Additionally, the use of foraminifera should preclude contamination by preformed riverine ferromanganese oxides, while foraminifera should be less sensitive to current transport or downslope transfer than bulk sediment leachates.

For the coretop sediments, there is excellent agreement between $\varepsilon_{\mathrm{Nd}}$ from uncleaned foraminifera and $\mathrm{HH}$ leachates on bulk decarbonated sediments, which agree within error at all 8 sites where both were measured (Figures 2 and 3). This suggests that both substrates are recording the same authigenic signal and that detrital contamination during leaching is not controlling the $\varepsilon_{\mathrm{Nd}}$ of the $\mathrm{HH}$ leachates in this case. Additionally, since the foraminifera are 
not decarbonated, it suggests that the decarbonation of bulk sediment may not be necessary for the recovery of bottom water $\varepsilon_{\mathrm{Nd}}$ values by $\mathrm{HH}$ leaching, which is further supported by the agreement with non-decarbonated $\mathrm{HH}$ leachates made at two of the sites (Figure 3). A good agreement between uncleaned foraminifera and non-decarbonated $\mathrm{HH}$ leachates is also observed for the Late Glacial reconstructions (Figure 3) and the WIND 28K deglacial record (Figure 4), which additionally provides some confidence in the stability of the Nd-carrying authigenic phases over the timescales relevant for glacial-interglacial study.

Considering coretop data from uncleaned foraminifera, WIND $5 \mathrm{~B}$ in the southern Madagascar Basin has an $\varepsilon_{\mathrm{Nd}}$ of -8.8 , which is consistent with the closest water profile from this basin (Bertram and Elderfield, 1993) (Figure 5a), while the northern and eastern Mascarene Basin sites WIND 30B, 32B and 35B have more radiogenic $\varepsilon_{\mathrm{Nd}}$ values of -7.3 to 7.9, which are also in agreement with nearby seawater profiles (Figure 5b); together, these provide confidence in our approach. Coretop uncleaned foraminifera data from WIND 10B, $12 \mathrm{~B}, 24 \mathrm{~B}$ and $28 \mathrm{~B}\left(\varepsilon_{\mathrm{Nd}}=-9.3\right.$ to -11.5$)$ on the western side of the Madagascar and Mascarene Basins are less radiogenic than recorded at these depths in the Bertram and Elderfield (1993) profiles from these basins (Figure 5). However, the water profiles are from the open ocean (Figure 1) and bottom water has not been measured along the Madagascan margin. This suggests that either (i) these foraminifera and leachates record bottom water along the margin, as at the other sites, but this does not match the open ocean $\varepsilon_{\mathrm{Nd}}$ profiles of Bertram and Elderfield (1993), or (ii) the authigenic phases at these sites are influenced by pore water and therefore record a very local signal.

A number of previous studies have discussed the question of bottom water versus pore water controls on the composition of authigenic sediment phases. In the case of diagenetic sediment coatings, foraminifera and fish teeth, it has been argued that the $\mathrm{Nd}$ is acquired either from bottom water or from shallow pore water (few $\mathrm{cm}$ depth) that is recording the same $\varepsilon_{\mathrm{Nd}}$ signature as bottom water (Palmer and Elderfield, 1985; Staudigel et al., 1985; Martin and Haley, 2000; Klevenz et al., 2008; Murphy and Thomas, 2010). The use of coretop samples ( $0-2 \mathrm{~cm}$ core depth) in our study is considered to minimise any possible pore water contributions. Additionally, the variance in the 8 coretop measurements is $\sim 6$ times smaller for the authigenic fraction than for the detrital sediments (Figure 2), thus ruling out a dominant control by detrital $\mathrm{Nd}$ released into pore water, since the variance would be expected to be similar in such a case. Therefore, in line with previous studies, we proceed to interpret the $\mathrm{Nd}$ isotopic composition of the authigenic fraction as a recorder of the bottom water composition, while recognising that further work on this question may be advised. In the following discussion we refer mostly to data from uncleaned foraminifera to characterise the authigenic $\varepsilon_{\mathrm{Nd}}$ since this represents our most extensive dataset, but given the good agreement between $\varepsilon_{\mathrm{Nd}}$ from multiple substrates (Figure 3) our conclusions are insensitive to this choice. 


\subsection{Spatial patterns record the influence of boundary exchange}

The Holocene authigenic $\mathrm{Nd}$ isotope data demonstrate spatial variability of $\sim 4 \varepsilon_{\mathrm{Nd}}$ units between 8 sites at similar depths in CDW (Figures 2, 3, 5). This spatial variability is over an order of magnitude greater than that predicted by conservative water mass mixing (Section 2), suggesting that local controls influence the $\mathrm{Nd}$ isotopic compositions. One feature of particular note is a shift towards less radiogenic values from south to north along the Madagascan margin, from $\varepsilon_{\mathrm{Nd}}=-8.8$ (WIND 5B) to $\varepsilon_{\mathrm{Nd}}=-11.5$ (WIND 24B) (Figure 2b). A second interesting feature is the more radiogenic $\varepsilon_{\mathrm{Nd}}$ composition measured in the eastern Mascarene Basin ( $\varepsilon_{\mathrm{Nd}}=-7.3$ to -7.9; WIND 30B, 32B, 35B) (Figure 2b).

The evolution of the reconstructed bottom water $\varepsilon_{\mathrm{Nd}}$ along the south to north flow path of CDW past Madagascar (Figures 2b, 3) is consistent with the identification of the Madagascar as an unradiogenic Nd source (Figure 2a). We rule out the dissolution of dust as a possible source due to the easterly wind directions (Schott and McCreary, 2001) and low dust mass accumulation rates (Kohfeld and Harrison, 2001; Mahowald et al., 2006). Dissolved riverine inputs might be more significant, but the water column $\varepsilon_{\mathrm{Nd}}$ profiles of Bertram and Elderfield (1993) show vertical gradients of 2-4 $\varepsilon_{\mathrm{Nd}}$ units (Figure 5) with the least radiogenic $\mathrm{Nd}$ in the deep ocean, which suggests that the source of unradiogenic $\mathrm{Nd}$ to bottom waters is located at depth. The simplest explanation for the observed spatial gradients (Figure 3) is therefore that the bottom water becomes progressively less radiogenic northwards due to the cumulative effect of boundary exchange with detrital sediments derived from the Madagascan shield. In this view, the less radiogenic authigenic $\varepsilon_{\mathrm{Nd}}$ values at WIND 24B than WIND 12B (Figure 3) reflect a longer pathway, and consequently longer time, for interaction between bottom water and the margin sediments.

The more radiogenic authigenic $\varepsilon_{\mathrm{Nd}}$ values in the northern and eastern Mascarene Basin (WIND 28B-35B; Figure 2b) may well involve boundary exchange but cannot be easily explained by the simple model described above for Madagascar. The authigenic $\varepsilon_{\mathrm{Nd}}$ shifts towards more radiogenic values from WIND 24B through WIND 28B to WIND 30B, while the detrital sediment also becomes more radiogenic but remains less radiogenic than the authigenic $\varepsilon_{\mathrm{Nd}}$ (Figure 3 ). The progressive shift towards more radiogenic $\varepsilon_{\mathrm{Nd}}$ values in the authigenic component implicates the boundary addition of $\mathrm{Nd}$ from volcanic sediments of Farquhar Ridge or the Mascarene Plateau, whereas the bulk detrital sediment appears to retain a strong Madagascan character (Figure 2a; Section 4.1). If the changes in the authigenic fraction are due to boundary exchange, this requires that the components that define the bulk detrital sediment $\varepsilon_{\mathrm{Nd}}$ do not contribute equally to the boundary exchange, and we infer a greater reactivity for a (radiogenic) basaltic volcanic component than the Madagascan shieldderived component. This may reflect the influence of mineralogy, but also potentially sediment lability. For example, the Madagascan inputs could include a highly labile and reactive phase that exchanges along the Madagascan margin but does not survive during the extended northward transport and re-circulation in the Mascarene Basin. In that case, by WIND $28 \mathrm{~B}$ and beyond, detrital volcanics could become the dominant reactive phase 
contributing to boundary exchange, even while Madagascan detrital sediments continue to have a strong control on the detrital silicate $\varepsilon_{\mathrm{Nd}}$ budget.

Alternatively, the steep $\varepsilon_{\mathrm{Nd}}$ gradient between WIND 24B and WIND 28B/30B (Figure 3 ) could reflect water mass mixing between northward-flowing CDW and southward-flowing NIDW. Unfortunately, the boundaries between these water masses are somewhat uncertain (e.g. Johnson et al., 1998; You, 2000; van Aken et al., 2004; McCave et al., 2005) and the Nd isotopic composition of NIDW is poorly characterised. We are therefore not able to rule out that the eastern cores WIND $30-35 \mathrm{~B}\left(\varepsilon_{\mathrm{Nd}}=-7.9\right.$ to -7.3 ; Figure 3$)$ are recording the composition of southward-flowing NIDW and that WIND 28B $\left(\varepsilon_{\mathrm{Nd}}=-9.3\right)$ records a mixture of this NIDW and Madagascan-influenced CDW.

\subsubsection{Quantification of the Madagascan boundary exchange}

A first order quantification of the extent of boundary exchange along the Madagascan margin requires the assumption that the margin's boundary exchange input is represented by the bulk detrital sediment $\varepsilon_{\mathrm{Nd}}$ (e.g. Arsouze et al., 2007; Jeandel et al., 2007; Arsouze et al., 2009). This approximation is likely to be true along most of the Madagascan margin, whereas northwards of WIND 24B volcanic sediment appears to form a greater part of the detrital mixture (Figure 2a) and may contribute preferentially to boundary exchange. A simple calculation for the Holocene (Table 4) then considers the inflowing CDW to have $\varepsilon_{\mathrm{Nd}}=-8.8$ (WIND 5B foraminifera), the Madagascan margin to have $\varepsilon_{\mathrm{Nd}}=-18.3$ (from the detrital sediment at WIND 10B and 12B) and the CDW at the northern end of the Madagascan margin to have $\varepsilon_{\mathrm{Nd}}=-11.5$ (WIND 24B foraminifera). If this is attributed simply to addition of $\mathrm{Nd}$, this implies that $\sim 29 \%$ of the bottom water $\mathrm{Nd}$ at the northern end of Madagascar has been derived from the margin (Table 4). This represents a minimum value since no correction has been made to account for any $\mathrm{Nd}$ removal along the margin (i.e. 'exchange'). For a deep water transport time along the margin of $\sim 120$ years (from modelling of radiocarbon data by Matsumoto and Key, 2004) this indicates a maximum deep water residence time for $\mathrm{Nd}$ of 400 years.

\subsection{Influences of water mass advection and boundary exchange on deglacial records}

The above evidence suggests that both water mass advection and boundary exchange controls need to be considered when interpreting downcore changes in the western Indian Ocean. With data from only one or two sediment cores, the question of advection versus boundary exchange controls may be hard to resolve, whereas we suggest that the spatial perspective from multiple sediment cores allows us to address this more quantitatively. Therefore, we first evaluate the Madagascan boundary exchange during the Late Glacial (Figures 2d, 3) before using this as a basis for interpreting deglacial changes (Figure 4).

During the Holocene, WIND 5B to the south of the margin records an advected signal of the inflowing CDW $\left(\varepsilon_{\mathrm{Nd}}=-8.8\right)$ that is unaffected by boundary exchange from Madagascar 
and is consistent with both Madagascar Basin and Southern Ocean water profiles today (Figure 5a). During the Late Glacial, foraminiferal $\varepsilon_{\mathrm{Nd}}$ at WIND $5 \mathrm{~K}$ is -7.2 (Figure 2d), indicating a glacial-interglacial shift of $\sim 1.6 \varepsilon_{\mathrm{Nd}}$ units, although this might be considered to represent a minimum change since a degree of bioturbational smoothing was recognised in the benthic oxygen isotope data from this low sedimentation rate core (McCave et al., 2005). Nevertheless, these data are in good agreement with the surface scrape of ferromanganese crust 109D-C in the Madagascar Basin (see Figure 1) which is expected to integrate recent glacial and interglacial periods and has $\varepsilon_{\mathrm{Nd}}=-7.6$ (O'Nions et al., 1998). This appears to confirm the reliability of the WIND $5 \mathrm{~B} / \mathrm{K}$ reconstruction in terms of both the recovery of seawater values and a lack of a significant boundary exchange influence between the inflow and this site.

The Madagascan margin sites (WIND 10, 12, 24, 28) also record more radiogenic values in the Late Glacial than in the Holocene (Figure 3), but with smaller magnitude glacialinterglacial shifts (1.0-1.2 $\varepsilon_{\mathrm{Nd}}$ units) than at WIND 5B/K. The same model as used for the Holocene (Table 4) demonstrates that the Late Glacial data from the Madagascan margin sites can be explained by a change in the inflow composition of $\sim 1.6 \varepsilon_{\mathrm{Nd}}$ units (as observed at WIND $5 \mathrm{~B} / \mathrm{K}$ ) and an unchanging balance between advection and boundary exchange. The smaller glacial-interglacial shifts at the margin sites are due to a buffering influence of the local sediment input (with an unchanging $\varepsilon_{\mathrm{Nd}}$ value in this area; Tables 2 and 3). The simplest explanation for this approximately constant boundary exchange influence in this region is that, to the extent that these are controls on the boundary exchange, there is no major change in the deep flow speed (e.g. McCave et al., 2005; Thomas et al., 2007) or sedimentary inputs between the Holocene and the Late Glacial, and no change in the wind-forced Rossby wave regime.

A more detailed record of deglacial changes is provided by the uncleaned foraminifera data from WIND 28K at the northern end of the Madagascan margin (Figure 4). Whereas the timing of the $\varepsilon_{\mathrm{Nd}}$ change in WIND $28 \mathrm{~K}$ at $\sim 14 \mathrm{ka} \mathrm{BP}$ coincides with the deglacial change in benthic carbon isotopes (Figure 4), the $\varepsilon_{\mathrm{Nd}}$ values at WIND $28 \mathrm{~K}$ are inconsistent with Holocene and Late Glacial data from WIND 5B/K in the deep inflow (Figure 6). The reduced magnitude of the glacial-interglacial shift at WIND 28K ( $\sim \varepsilon_{\mathrm{Nd}}$ unit) can be explained by a partial buffering towards the margin composition due to boundary exchange, as expected from the Holocene and Late Glacial transects (Figure 3, Table 4).

Controls by local buffering might also explain the discrepancy between WIND $5 \mathrm{~K}$ and an existing $\varepsilon_{\mathrm{Nd}}$ record from V19-188 at $3356 \mathrm{~m}$ water depth on the north-eastern margin of the Mascarene Plateau (Pahnke et al., 2008; Figures 1 and 6). Late Glacial $\varepsilon_{\mathrm{Nd}}$ values of -4.2 in V19-188 appear surprisingly radiogenic and, if these are to be explained by a boundary exchange control, this requires a different temporal evolution of boundary exchange on the eastern flank of the Mascarene Plateau to that observed on the Madagascan margin (Table 4). Since V19-188 is presently ventilated by NIDW (re-circulated CDW) flowing from the north Indian Ocean (Mantyla and Reid, 1995), and given the radiogenic $\varepsilon_{\mathrm{Nd}}$ composition of the margins of the northwest Indian Ocean (Jeandel et al., 2007), a more radiogenic Nd isotopic 
composition for NIDW than CDW could be produced if boundary exchange increased within this region during the glacial.

\subsection{Geographic extent and paleoceanographic implications of boundary exchange}

The Holocene shift of $\sim 2.7 \varepsilon_{\mathrm{Nd}}$ units along the Madagascan margin implies that $\geq 29 \%$ of the Nd has been acquired from the margin. This is comparable to modern day observations from North West Atlantic Bottom Water as it flows along the south-west Greenland and Labrador continental margins (Lacan and Jeandel, 2005), where a similar calculation would imply a boundary source of $\sim 20 \%$. This indicates that the observations of Lacan and Jeandel (2005) are more widely applicable beyond the North Atlantic region, and in particular that sediment derived from granitic terrains can contribute to boundary exchange without requiring a special case of glaciation. This contrasts with the suggestion of Jones et al. (2008) that boundary exchange may be restricted to volcanic sediments in the deep Pacific Ocean, and instead provides support for recent modelling studies which argue that boundary exchange exerts a strong control on seawater Nd isotopes globally (Arsouze et al., 2009; Rempfer et al., 2011). We note that our first order estimate of the (regional) deep water $\mathrm{Nd}$ residence time ( $\leq 400$ years) is consistent with the global estimates of those studies (360 years in Arsouze et al., 2009; 700 years in Rempfer et al., 2011), but our work also raises two challenges to such modelling studies. First, together with findings in the Angola Basin (Rickli et al., 2009), our data indicate a boundary exchange influence in the deep ocean at $\sim 4 \mathrm{~km}$ water depth, suggesting a revision to the assumption that boundary exchange is a depthdependent process which decreases to zero below $3 \mathrm{~km}$ water depth (e.g. Arsouze et al., 2007, 2009; Rempfer et al., 2011). Secondly, and more speculatively, we suggest that in cases of mixed lithologies, the sediment components that define the bulk detrital $\varepsilon_{\mathrm{Nd}}$ may not contribute equally to the boundary exchange, as a function of mineralogy, lability and/or specific surface area, and that more work investigating this question is required.

A comparison with existing reconstructions of the CDW composition provides further evidence on the geographical extent of boundary exchange (Figure 6). Core RC11-83 in the deep Cape Basin of the southeast Atlantic (Piotrowski et al., 2005) records Holocene (0-10 ka) $\varepsilon_{\mathrm{Nd}}$ values of $-8.8 \pm 1.0(2 \sigma, \mathrm{n}=19)$ and Late Glacial (20 to $\left.30 \mathrm{ka}\right) \varepsilon_{\mathrm{Nd}}$ values of $-6.8 \pm 0.6$ $(2 \sigma, \mathrm{n}=21)$, which agree with those from WIND $5 \mathrm{~B} / \mathrm{K}$ (Holocene $\varepsilon_{\mathrm{Nd}}=-8.8 \pm 0.3$; Late Glacial $\varepsilon_{\mathrm{Nd}}=-7.2 \pm 0.3$ ). The WIND 5K Late Glacial value is also consistent with the only existing reconstructions of $\varepsilon_{\mathrm{Nd}}$ in the glacial Southern Ocean: a Heinrich 1 age coral from $1.1 \mathrm{~km}$ water depth in the Drake Passage (-6.4 \pm 0.4 ; Robinson and van de Flierdt, 2009) and a Marine Isotope Stage 3 coral from $2.5 \mathrm{~km}$ water depth in the Amundsen Sea (-6.8 \pm 0.3 ; Hoffmann et al., 2008). This suggests that $\mathrm{Nd}$ isotopes may be advected conservatively in volumetrically large portions of the deep open ocean outside of the influence of major reactive detrital inputs; for example between the southern South Atlantic and western Indian Ocean, via the Atlantic sector of the Southern Ocean. Such conservative behaviour in the Antarctic Circumpolar Current has recently been demonstrated in modern seawater studies (Carter et al., 2012; Stichel et al., 2012) and we show that this was apparently true during both 
the Holocene and Late Glacial periods. The implication is that evidence on the $\varepsilon_{\mathrm{Nd}}$ evolution of the Southern Ocean end member through time may be obtained from WIND 5K or RC1183 (Piotrowski et al., 2005), but not from WIND 28K or V19-188 (Pahnke et al., 2008).

Finally, we have demonstrated that in a scenario where the relative importance of advection and boundary exchange is unchanged and the composition of the detrital input is also unchanged, boundary exchange can represent a buffering influence on the magnitude of temporal variations recorded in authigenic $\mathrm{Nd}$ isotope records. This may be important for the paleoceanographic interpretation of records from other locations and must be evaluated on a site by site basis. For example, an approximately constant boundary exchange influence on the Californian margin could explain the muted temporal variability observed by Murphy and Thomas (2010) at a marginal site compared to an open ocean site.

\section{Conclusions}

$\mathrm{Nd}$ isotope data from uncleaned foraminifera and bulk sediment leachates record a consistent picture of spatial variability along the Madagascar and Mascarene margins during the Holocene. Total variability of $\sim 4 \varepsilon_{\mathrm{Nd}}$ units is interpreted in terms of a boundary exchange influence on the bottom water composition in two contrasting detrital sediment regimes. Bottom water along the Madagascan margin (e.g. WIND 12B, 24B) is influenced by highly unradiogenic sediment inputs from the Madagascan shield, while the more radiogenic bottom water compositions in the northern and eastern Mascarene Basin (e.g. WIND 30-35B) may indicate a role for boundary exchange with volcanic sediments from the Farquhar Ridge and Mascarene Plateau (or mixing with NIDW which acquired this more radiogenic $\varepsilon_{\mathrm{Nd}}$ signal in the northern Indian Ocean). There is also an influence of Rossby wave-driven oscillatory flow, which leads to a diffusive smearing of the detrital sediment signatures both in advance of (e.g. WIND 10B) and between (e.g. WIND 28B) these two main input sources.

The shift of $\sim 2.7 \varepsilon_{\mathrm{Nd}}$ units between the CDW inflow (recorded in WIND 5B) and the northern Madagascan margin (WIND 24B) suggests that $\mathrm{Nd}$ has a relatively short residence time ( $\leq 400$ years) in such locations, consistent with observations from the modern water column of the North Atlantic (e.g. Lacan and Jeandel, 2005) and with recent global modelling studies (e.g. Arsouze et al., 2009; Rempfer et al., 2011). This demonstrates that boundary exchange can occur from old granitic shield material (perhaps via continental weathering and the formation of reactive particles) and is not restricted to volcanic sediments or ash (cf. Jones et al., 2008) or fine "glacial flour". Further, we have demonstrated a boundary exchange control in the deep ocean $(4 \mathrm{~km})$, which contrasts with the above modelling studies which have assumed that boundary exchange below $3 \mathrm{~km}$ water depth is insignificant.

Deglacial $\varepsilon_{\mathrm{Nd}}$ changes in the western Indian Ocean can be explained by a change of $1.6 \varepsilon_{\mathrm{Nd}}$ units in the advected composition of the CDW inflow plus a buffering effect of boundary exchange, which appears to be constant between the Late Glacial and Holocene periods along the Madagascan margin. The similarity between WIND 5K ( $700 \mathrm{~km}$ south of Madagascar) and other Southern Ocean $\varepsilon_{\mathrm{Nd}}$ records suggests that boundary exchange is 
mostly restricted to ocean margins rather than the open ocean, whereas $\mathrm{Nd}$ isotope records from ocean margin sites (e.g. WIND 24K, 28K) record both global ocean circulation changes and more local boundary exchange influences. This demonstrates the importance of a spatial perspective for the interpretation of paleo-records. We suggest that by identifying sites little affected by boundary exchange (for example, those significantly upstream of a margin) we might obtain the dominant circulation signal, while studies along ocean margins may instead provide evidence on the changing fluxes of rare earth elements and other particle-reactive elements between the continents and the oceans.

\section{Acknowledgements}

We thank Jo Clegg and Jason Day for laboratory and MC-ICP-MS support, and David Hodell and Yama Dixit for their assistance with coulometry measurements. We also thank Luke Skinner and Gideon Henderson for discussion, and Marcus Gutjahr, Katharina Pahnke and an anonymous reviewer for their helpful comments on the manuscript. This study was supported by NERC grant NE/F006047/1, RG50124 LBZG/036 "Reconstructing past changes in global thermohaline circulation" to AMP/AG and a NERC studentship to DJW. Sampling was funded by NERC grant NER/A/S/2000/00493 and ship time to INMcC.

\section{References}

Arsouze, T., Dutay, J.C., Lacan, F., Jeandel, C., 2007. Modeling the neodymium isotopic composition with a global ocean circulation model. Chemical Geology 239, 165-177.

Arsouze, T., Dutay, J.C., Lacan, F., Jeandel, C., 2009. Reconstructing the Nd oceanic cycle using a coupled dynamical - biogeochemical model. Biogeosciences 6, 2829-2846.

Bayon, G., Burton, K.W., Soulet, G., Vigier, N., Dennielou, B., Etoubleau, J., Ponzevera, E., German, C.R., Nesbitt, R.W., 2009. Hf and Nd isotopes in marine sediments: Constraints on global silicate weathering. Earth Planet. Sci. Lett. 277, 318-326.

Bayon, G., German, C.R., Boella, R.M., Milton, J.A., Taylor, R.N., Nesbitt, R.W., 2002. An improved method for extracting marine sediment fractions and its application to $\mathrm{Sr}$ and $\mathrm{Nd}$ isotopic analysis. Chemical Geology 187, 179-199.

Bayon, G., German, C.R., Burton, K.W., Nesbitt, R.W., Rogers, N., 2004. Sedimentary FeMn oxyhydroxides as paleoceanographic archives and the role of aeolian flux in regulating oceanic dissolved REE. Earth Planet. Sci. Lett. 224, 477-492.

Bertram, C.J., Elderfield, H., 1993. The geochemical balance of the rare-earth elements and neodymium isotopes in the oceans. Geochim. Cosmochim. Acta 57, 1957-1986. 
Bosch, D., Blichert-Toft, J., Moynier, F., Nelson, B.K., Telouk, P., Gillot, P.Y., Albarede, F., 2008. $\mathrm{Pb}$, Hf and $\mathrm{Nd}$ isotope compositions of the two Reunion volcanoes (Indian Ocean): A tale of two small-scale mantle "blobs"? Earth Planet. Sci. Lett. 265, 748-768.

Broecker, W.S., Peng, T.H., 1982. Tracers in the Sea. Eldigio Press.

Carter, P., Vance, D., Hillenbrand, C.D., Smith, J.A., Shoosmith, D.R., 2012. The neodymium isotopic composition of waters masses in the eastern Pacific sector of the Southern Ocean. Geochim. Cosmochim. Acta 79, 41-59.

Chester, R., Hughes, M.J., 1967. A chemical technique for the separation of ferro-manganese minerals, carbonate minerals and adsorbed trace elements from pelagic sediments. Chemical Geology 2, 249-262.

Donohue, K.A., Toole, J.M., 2003. A near-synoptic survey of the Southwest Indian Ocean. Deep-Sea Res. Part II-Top. Stud. Oceanogr. 50, 1893-1931.

Elmore, A.C., Piotrowski, A.M., Wright, J.D., Scrivner, A.E., 2011. Testing the extraction of past seawater $\mathrm{Nd}$ isotopic composition from North Atlantic deep sea sediments and foraminifera. Geochem. Geophys. Geosyst. 12, Q09008, doi:10.1029/2011GC003741.

Frank, M., 2002. Radiogenic isotopes: Tracers of past ocean circulation and erosional input. Rev. Geophys. 40, doi:10.1029/2000RG000094.

Ganachaud, A., Wunsch, C., Marotzke, J., Toole, J., 2000. Meridional overturning and largescale circulation of the Indian Ocean. J. Geophys. Res.-Oceans 105, 26117-26134.

Goldstein, S.L., Hemming, S.R., 2003. Long-lived isotopic tracers in oceanography, paleoceanography and ice sheet dynamics, in: Elderfield, H. (Ed.), The Oceans and Marine Geochemistry. Elsevier-Pergamon, Oxford, pp. 453-489.

Gutjahr, M., Frank, M., Stirling, C.H., Keigwin, L.D., Halliday, A.N., 2008. Tracing the Nd isotope evolution of North Atlantic deep and intermediate waters in the Western North Atlantic since the Last Glacial Maximum from Blake Ridge sediments. Earth Planet. Sci. Lett. 266, 61-77.

Gutjahr, M., Frank, M., Stirling, C.H., Klemm, V., van de Flierdt, T., Halliday, A.N., 2007. Reliable extraction of a deepwater trace metal isotope signal from Fe-Mn oxyhydroxide coatings of marine sediments. Chemical Geology 242, 351-370.

Hoffmann, D., Gutjahr, M., Vance, D., Hillenbrand, C.D., 2008. Antarctic Circumpolar Current Nd isotope variability recorded in Amundsen Sea deep sea corals. Geochim. Cosmochim. Acta 72, A383-A383. 
Horikawa, K., Martin, E.E., Asahara, Y., Sagawa, T., 2011. Limits on conservative behavior of $\mathrm{Nd}$ isotopes in seawater assessed from analysis of fish teeth from Pacific core tops. Earth Planet. Sci. Lett. 310, 119-130.

Jacobsen, S.B., Wasserburg, G.J., 1980. Sm-Nd isotopic composition of chondrites. Earth Planet. Sci. Lett. 50, 139-155.

Jeandel, C., Arsouze, T., Lacan, F., Techine, P., Dutay, J.C., 2007. Isotopic Nd compositions and concentrations of the lithogenic inputs into the ocean: A compilation, with an emphasis on the margins. Chemical Geology 239, 156-164.

Johnson, G.C., Musgrave, D.L., Warren, B.A., Ffield, A., Olson, D.B., 1998. Flow of bottom and deep water in the Amirante Passage and Mascarene Basin. J. Geophys. Res.-Oceans 103, 30973-30984.

Jones, K.M., Khatiwala, S.P., Goldstein, S.L., Hemming, S.R., van de Flierdt, T., 2008. Modeling the distribution of $\mathrm{Nd}$ isotopes in the oceans using an ocean general circulation model. Earth Planet. Sci. Lett. 272, 610-619.

Kiefer, T., McCave, I.N., Elderfield, H., 2006. Antarctic control on tropical Indian Ocean sea surface temperature and hydrography. Geophys. Res. Lett. 33, L24612,

doi:10.1029/2006GL027097.

Klevenz, V., Vance, D., Schmidt, D.N., Mezger, K., 2008. Neodymium isotopes in benthic foraminifera: Core-top systematics and a down-core record from the Neogene south Atlantic. Earth Planet. Sci. Lett. 265, 571-587.

Kohfeld, K.E., Harrison, S.P., 2001. DIRTMAP: the geological record of dust. Earth-Sci. Rev. 54, 81-114.

Kroner, A., Hegner, E., Collins, A.S., Windley, B.F., Brewer, T.S., Razakamanana, T., Pidgeon, R.T., 2000. Age and magmatic history of the Antananarivo Block, central Madagascar, as derived from zircon geochronology and Nd isotopic systematics. Am. J. Sci. 300, 251-288.

Lacan, F., Jeandel, C., 2005. Neodymium isotopes as a new tool for quantifying exchange fluxes at the continent-ocean interface. Earth Planet. Sci. Lett. 232, 245-257.

Mahoney, J., Nicollet, C., Dupuy, C., 1991. Madagascar basalts: tracking oceanic and continental sources. Earth Planet. Sci. Lett. 104, 350-363.

Mahowald, N.M., Muhs, D.R., Levis, S., Rasch, P.J., Yoshioka, M., Zender, C.S., Luo, C., 2006. Change in atmospheric mineral aerosols in response to climate: Last glacial period, preindustrial, modern, and doubled carbon dioxide climates. J. Geophys. Res.-Atmos. 111, D10202, doi:10.1029/2005JD006653. 
Mantyla, A.W., Reid, J.L., 1995. On the origins of deep and bottom waters of the Indian Ocean. J. Geophys. Res.-Oceans 100, 2417-2439.

Martin, E.E., Blair, S.W., Kamenov, G.D., Scher, H.D., Bourbon, E., Basak, C., Newkirk, D.N., 2010. Extraction of Nd isotopes from bulk deep sea sediments for paleoceanographic studies on Cenozoic time scales. Chemical Geology 269, 414-431.

Martin, E.E., Haley, B.A., 2000. Fossil fish teeth as proxies for seawater $\mathrm{Sr}$ and $\mathrm{Nd}$ isotopes. Geochim. Cosmochim. Acta 64, 835-847.

Matsumoto, K., Key, R., 2004. Natural radiocarbon distribution in the deep ocean, in: Shiomi, M., Kawahata, H. (Eds.), Global Environmental Change in the Ocean and on Land. TERRAPUB, Tokyo, pp. 45-58.

McCave, I.N., 2001. RRS Charles Darwin cruise 129 report. Department of Earth Science, University of Cambridge, UK.

McCave, I.N., Kiefer, T., Thornalley, D.J.R., Elderfield, H., 2005. Deep flow in the Madagascar-Mascarene Basin over the last 150000 years. Philosophical Transactions of the Royal Society of London Series a-Mathematical Physical and Engineering Sciences 363, 8199.

McLennan, S.M., Taylor, S.R., McCulloch, M.T., Maynard, J.B., 1990. Geochemical and NdSr isotopic composition of deep-sea turbidites: Crustal evolution and plate tectonic associations. Geochim. Cosmochim. Acta 54, 2015-2050.

Murphy, D.P., Thomas, D.J., 2010. The negligible role of intermediate water circulation in stadial-interstadial oxygenation variations along the southern California margin: Evidence from Nd isotopes. Quat. Sci. Rev. 29, 2442-2450.

O'Nions, R.K., Carter, S.R., Cohen, R.S., Evensen, N.M., Hamilton, P.J., 1978. Pb, Nd and Sr isotopes in oceanic ferromanganese deposits and ocean floor basalts. Nature 273, 435-438.

O'Nions, R.K., Frank, M., von Blanckenburg, F., Ling, H.F., 1998. Secular variation of Nd and $\mathrm{Pb}$ isotopes in ferromanganese crusts from the Atlantic, Indian and Pacific Oceans. Earth Planet. Sci. Lett. 155, 15-28.

Pahnke, K., Goldstein, S.L., Hemming, S.R., 2008. Abrupt changes in Antarctic Intermediate Water circulation over the past 25,000 years. Nat. Geosci. 1, 870-874.

Palmer, M.R., 1985. Rare earth elements in foraminifera tests. Earth Planet. Sci. Lett. 73, 285298.

Palmer, M.R., Elderfield, H., 1985. Variations in the Nd isotopic composition of foraminifera from Atlantic Ocean sediments. Earth Planet. Sci. Lett. 73, 299-305. 
Palmer, M.R., Elderfield, H., 1986. Rare earth elements and neodymium isotopes in ferromanganese oxide coatings of Cenozoic foraminifera from the Atlantic Ocean. Geochim. Cosmochim. Acta 50, 409-417.

Paquette, J.L., Nedelec, A., Moine, B., Rakotondrazafy, M., 1994. U-Pb, single zircon Pbevaporation, and Sm-Nd isotopic study of a granulite domain in SE Madagascar. J. Geol. 102, 523-538.

Piepgras, D.J., Wasserburg, G.J., 1980. Neodymium isotopic variations in seawater. Earth Planet. Sci. Lett. 50, 128-138.

Piepgras, D.J., Wasserburg, G.J., 1982. Isotopic composition of neodymium in waters from the Drake Passage. Science 217, 207-214.

Piepgras, D.J., Wasserburg, G.J., Dasch, E.J., 1979. The isotopic composition of Nd in different ocean masses. Earth Planet. Sci. Lett. 45, 223-236.

Piotrowski, A.M., Banakar, V.K., Scrivner, A.E., Elderfield, H., Galy, A., Dennis, A., 2009. Indian Ocean circulation and productivity during the last glacial cycle. Earth Planet. Sci. Lett. 285, 179-189.

Piotrowski, A.M., Goldstein, S.L., Hemming, S.R., Fairbanks, R.G., 2005. Temporal relationships of carbon cycling and ocean circulation at glacial boundaries. Science 307, 1933-1938.

Piotrowski, A.M., Goldstein, S.L., Hemming, S.R., Fairbanks, R.G., Zylberberg, D.R., 2008. Oscillating glacial northern and southern deep water formation from combined neodymium and carbon isotopes. Earth Planet. Sci. Lett. 272, 394-405.

Pomies, C., Davies, G.R., Conan, S.M.H., 2002. Neodymium in modern foraminifera from the Indian Ocean: implications for the use of foraminiferal $\mathrm{Nd}$ isotope compositions in paleooceanography. Earth Planet. Sci. Lett. 203, 1031-1045.

Rempfer, J., Stocker, T.F., Joos, F., Dutay, J.C., Siddall, M., 2011. Modelling Nd-isotopes with a coarse resolution ocean circulation model: Sensitivities to model parameters and source/sink distributions. Geochim. Cosmochim. Acta 75, 5927-5950.

Rickli, J., Frank, M., Halliday, A.N., 2009. The hafnium-neodymium isotopic composition of Atlantic seawater. Earth Planet. Sci. Lett. 280, 118-127.

Roberts, N.L., Piotrowski, A.M., McManus, J.F., Keigwin, L.D., 2010. Synchronous deglacial overturning and water mass source changes. Science 327, 75-78.

Robinson, L.F., van de Flierdt, T., 2009. Southern Ocean evidence for reduced export of North Atlantic Deep Water during Heinrich event 1. Geology 37, 195-198. 
Rutberg, R.L., Hemming, S.R., Goldstein, S.L., 2000. Reduced North Atlantic Deep Water flux to the glacial Southern Ocean inferred from neodymium isotope ratios. Nature 405, 935938.

Schott, F.A., McCreary, J.P., 2001. The monsoon circulation of the Indian Ocean. Prog. Oceanogr. 51, 1-123.

Siddall, M., Khatiwala, S., van de Flierdt, T., Jones, K., Goldstein, S.L., Hemming, S., Anderson, R.F., 2008. Towards explaining the $\mathrm{Nd}$ paradox using reversible scavenging in an ocean general circulation model. Earth Planet. Sci. Lett. 274, 448-461.

Staudigel, H., Doyle, P., Zindler, A., 1985. Sr and Nd isotope systematics in fish teeth. Earth Planet. Sci. Lett. 76, 45-56.

Stichel, T., Frank, M., Rickli, J., Haley, B.A., 2012. The hafnium and neodymium isotope composition of seawater in the Atlantic sector of the Southern Ocean. Earth Planet. Sci. Lett. 317, 282-294.

Stumpf, R., Frank, M., Schonfeld, J., Haley, B.A., 2010. Late Quaternary variability of Mediterranean Outflow Water from radiogenic Nd and Pb isotopes. Quat. Sci. Rev. 29, 24622472.

Tachikawa, K., Athias, V., Jeandel, C., 2003. Neodymium budget in the modern ocean and paleo-oceanographic implications. J. Geophys. Res.-Oceans 108, doi:10.1029/1999JC000285.

Tachikawa, K., Jeandel, C., Roy-Barman, M., 1999. A new approach to the Nd residence time in the ocean: the role of atmospheric inputs. Earth Planet. Sci. Lett. 170, 433-446.

Tanaka, T., Togashi, S., Kamioka, H., Amakawa, H., Kagami, H., Hamamoto, T., Yuhara, M., Orihashi, Y., Yoneda, S., Shimizu, H., Kunimaru, T., Takahashi, K., Yanagi, T., Nakano, T., Fujimaki, H., Shinjo, R., Asahara, Y., Tanimizu, M., Dragusanu, C., 2000. JNdi-1: a neodymium isotopic reference in consistency with LaJolla neodymium. Chemical Geology $168,279-281$.

Thomas, A.L., Henderson, G.M., McCave, I.N., 2007. Constant bottom water flow into the Indian Ocean for the past $140 \mathrm{ka}$ indicated by sediment ${ }^{231} \mathrm{~Pa} /{ }^{230} \mathrm{Th}$ ratios. Paleoceanography 22, PA4210, doi:10.1029/2007PA001415.

van Aken, H.M., Ridderinkhof, H., de Ruijter, W.P.M., 2004. North Atlantic deep water in the south-western Indian ocean. Deep-Sea Res. Part I-Oceanogr. Res. Pap. 51, 755-776.

Vance, D., Scrivner, A.E., Beney, P., Staubwasser, M., Henderson, G.M., Slowey, N.C., 2004. The use of foraminifera as a record of the past neodymium isotope composition of seawater. Paleoceanography 19, PA2009, doi:10.1029/2003PA000957. 
von Blanckenburg, F., 1999. Perspectives: Paleoceanography - Tracing past ocean circulation? Science 286, 1862-1863.

Warren, B.A., Whitworth, T., LaCasce, J.H., 2002. Forced resonant undulation in the deep Mascarene Basin. Deep-Sea Res. Part II-Top. Stud. Oceanogr. 49, 1513-1526.

Wasserburg, G.J., Jacobsen, S.B., Depaolo, D.J., McCulloch, M.T., Wen, T., 1981. Precise determination of $\mathrm{Sm} / \mathrm{Nd}$ ratios, $\mathrm{Sm}$ and $\mathrm{Nd}$ isotopic abundances in standard solutions.

Geochim. Cosmochim. Acta 45, 2311-2323.

White, W.M., Cheatham, M.M., Duncan, R.A., 1990. Isotope geochemistry of leg 115 basalts and inferences on the history of the Reunion mantle plume. Proceedings of the Ocean Drilling Program Scientific Results 115, 53-61.

You, Y., 2000. Implications of the deep circulation and ventilation of the Indian Ocean on the renewal mechanism of North Atlantic Deep Water. J. Geophys. Res.-Oceans 105, 2389523926.

Yu, J.M., Broecker, W.S., Elderfield, H., Jin, Z.D., McManus, J., Zhang, F., 2010. Loss of carbon from the deep sea since the Last Glacial Maximum. Science 330, 1084-1087. 


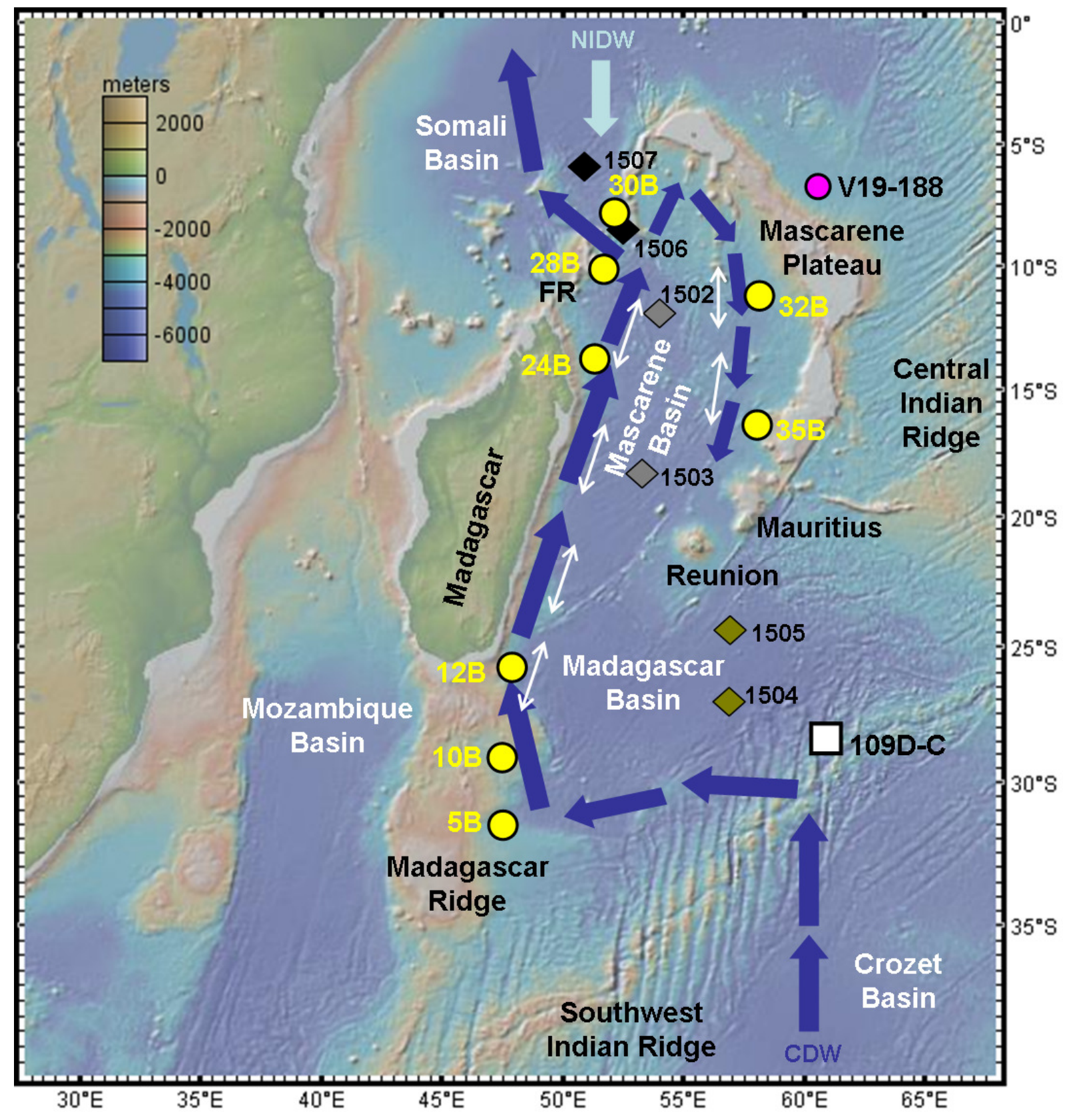

Figure 1: Western Indian Ocean map showing locations of WIND sediment cores (yellow circles and labels; see Table 1 for core depths). Also shown are the locations of water column $\varepsilon_{\mathrm{Nd}}$ profiles from Bertram and Elderfield (1993; sites CD1502-1507; diamonds labelled with their numeric identifier and colour coded according to their location; see Figure 5), ferromanganese crust 109D-C $\left(28{ }^{\circ} \mathrm{S}, 61{ }^{\circ} \mathrm{E}, 5200-5700 \mathrm{~m}\right.$ water depth; white square; O'Nions et al., 1998) and sediment core V19-188 (6.87 ${ }^{\circ} \mathrm{S}, 60.67{ }^{\circ} \mathrm{E}, 3356 \mathrm{~m}$ water depth; pink circle; Pahnke et al., 2008). Schematic deep water flow paths of CDW and NIDW are shown by dark blue and light blue arrows, respectively (redrawn from McCave et al., 2005); for more detailed hydrography, including the detailed flow paths of NIDW and AAIW at shallower depths, see McCave et al. (2005). North-south oscillations in the deep flow in the Mascarene Basin are caused by Rossby waves (Warren et al., 2002) and are represented by white double-headed arrows. FR = Farquhar Ridge. Base map from GeoMapApp. 

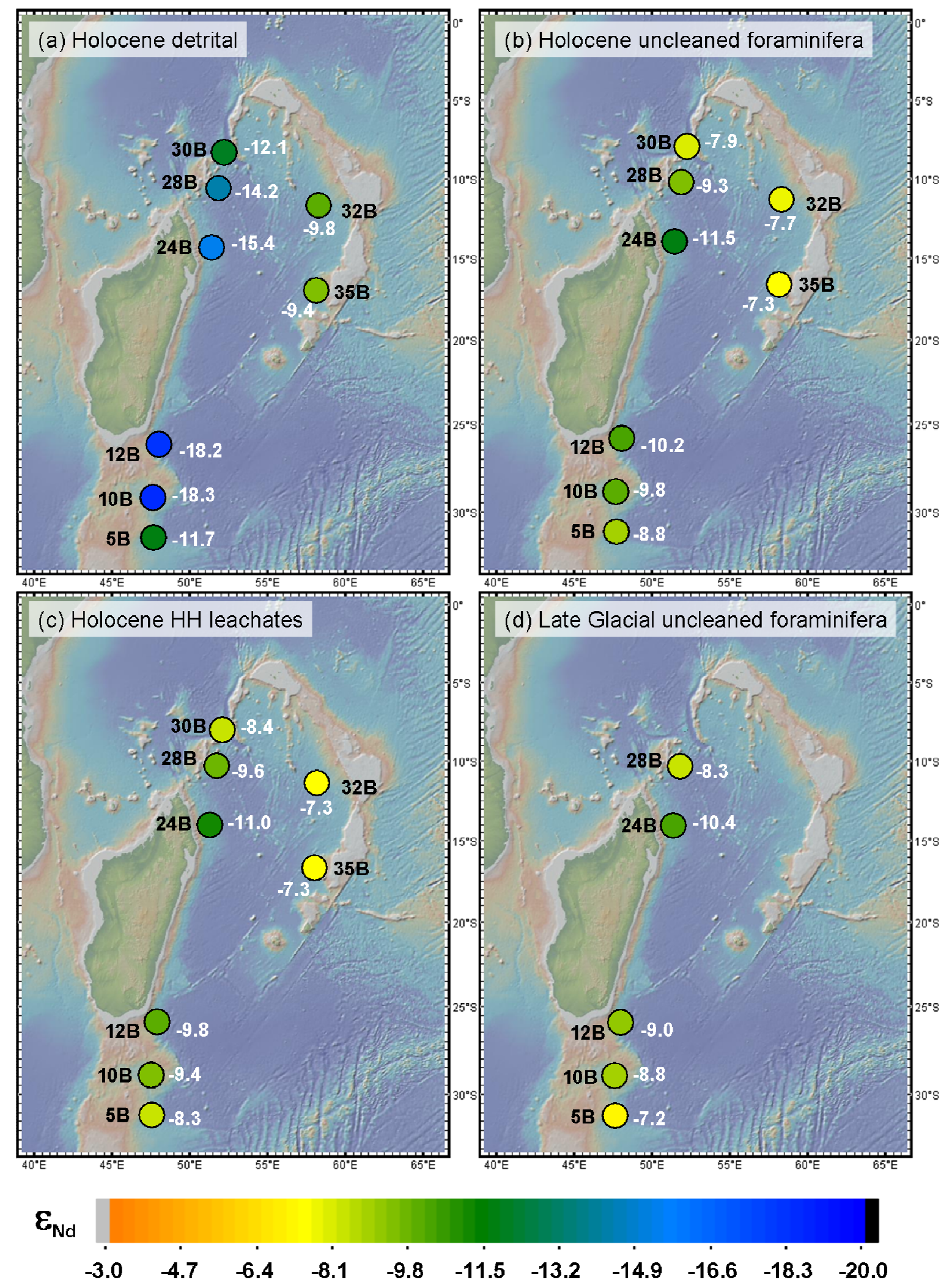

Figure 2: Spatial patterns of Nd isotopic variability in WIND cores: (a) Holocene detrital sediments, (b) Holocene uncleaned foraminifera, (c) Holocene decarbonated $\mathrm{HH}$ leachates and (d) Late Glacial uncleaned foraminifera. The measurements have typical $2 \sigma \sim 0.3 \varepsilon_{\mathrm{Nd}}$ units in all panels, with the exception of panel (b) with $2 \sigma \sim 0.5 \varepsilon_{\mathrm{Nd}}$ units. Base map from GeoMapApp. 


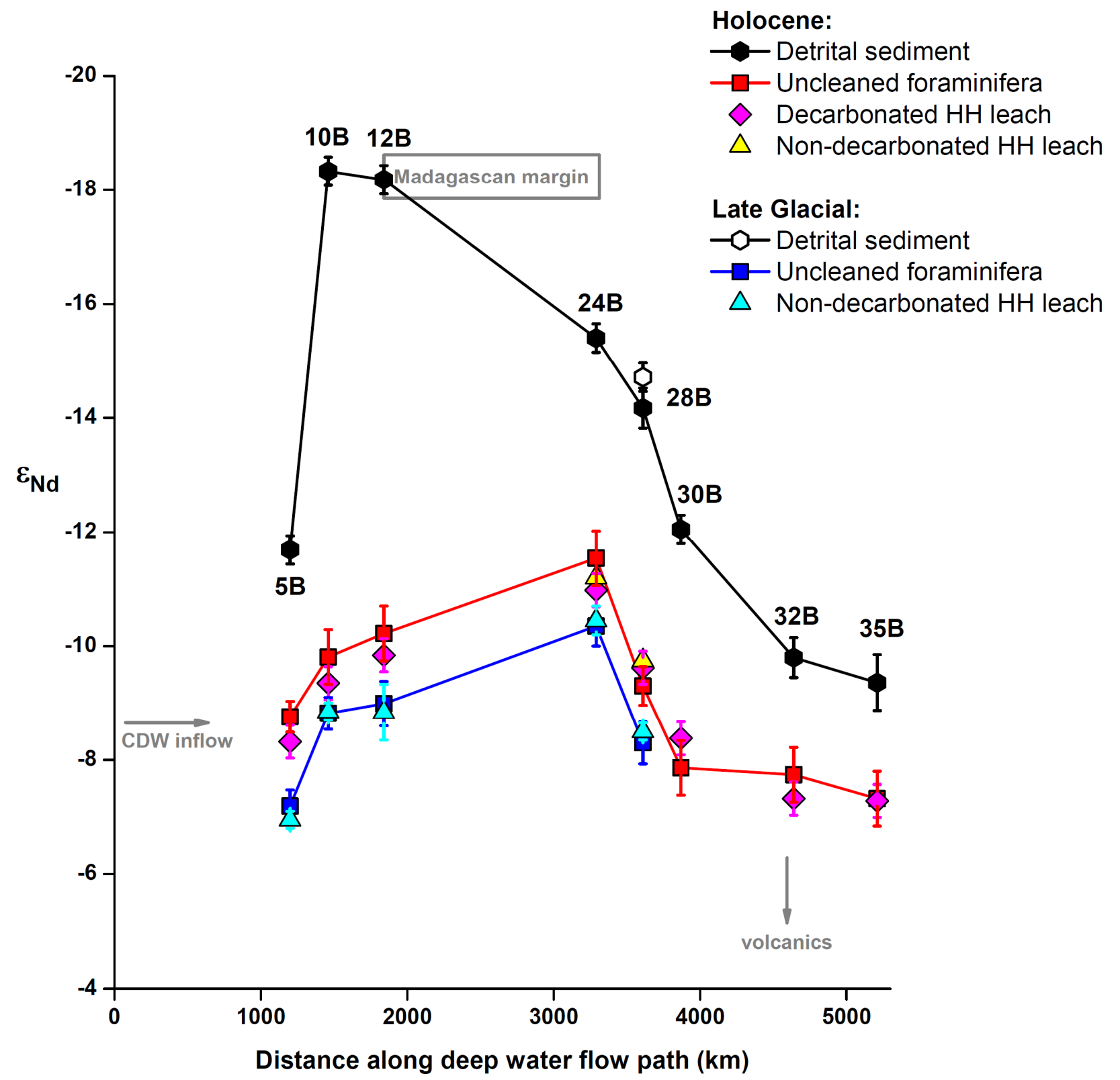

Figure 3: $\mathrm{Nd}$ isotope data plotted versus approximate distance along the CDW flow path (distance runs from the Madagascar Basin inflow to WIND 5B, northwards to WIND 30B and then clockwise around the Mascarene Basin to WIND 35B; see Figure 1). The detrital sediment $\varepsilon_{\mathrm{Nd}}$ is plotted in black with core identifier labels, while the authigenic $\varepsilon_{\mathrm{Nd}}$ data are plotted in warm colours for the Holocene and cool colours for the Late Glacial. Red and blue lines connect the data from uncleaned foraminifera for the Holocene and Late Glacial, respectively. The grey arrow labelled 'CDW inflow' indicates the approximate composition of CDW flowing into the Madagascar Basin from the Southern Ocean (see Figure 5a; Bertram and Elderfield, 1993; Stichel et al., 2012). The grey box labelled 'Madagascan margin' indicates the approximate geographical extent and estimated $\varepsilon_{\mathrm{Nd}}$ composition of the detrital sediment on this margin. The grey arrow labelled 'volcanics' points in the direction of the expected $\varepsilon_{\mathrm{Nd}}$ composition of a basaltic volcanic component inferred to be present as part of the detrital sediment mixture in the Mascarene Basin. Error bars on the data points represent $2 \sigma$. Note the reversed y axis scale for the $\varepsilon_{\mathrm{Nd}}$ data. 


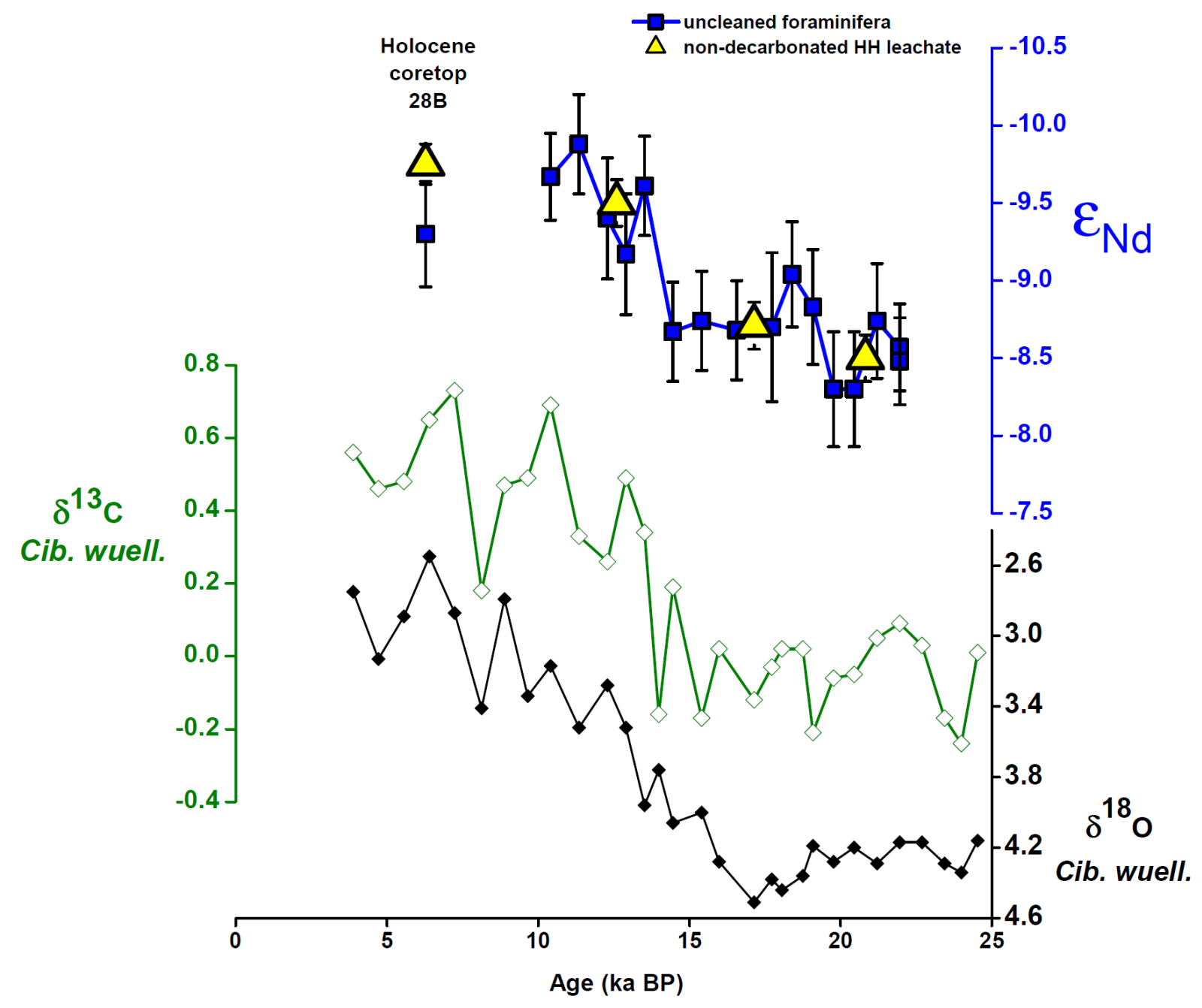

Figure 4: WIND $28 \mathrm{~K}$ deglacial $\varepsilon_{\mathrm{Nd}}$ data from uncleaned foraminifera (blue squares) and nondecarbonated $\mathrm{HH}$ leachates (yellow triangles), compared to benthic $\delta^{18} \mathrm{O}$ (closed black diamonds) and benthic $\delta^{13} \mathrm{C}$ (open green diamonds) from Cibicidoides wuellerstorfi (McCave et al., 2005). The age model for WIND 28K is from Yu et al. (2010), after Kiefer et al. (2006). The Holocene coretop $\varepsilon_{\mathrm{Nd}}$ data from WIND 28B are also plotted at $\sim 6.3 \mathrm{ka}$, after converting radiocarbon age (Table 1) to calendar age using the Fairbanks0107 calibration (with no reservoir age correction applied). Error bars on the $\varepsilon_{\mathrm{Nd}}$ data points represent $2 \sigma$. Note the reversed y axis scale for the $\varepsilon_{\mathrm{Nd}}$ data. 
(a)

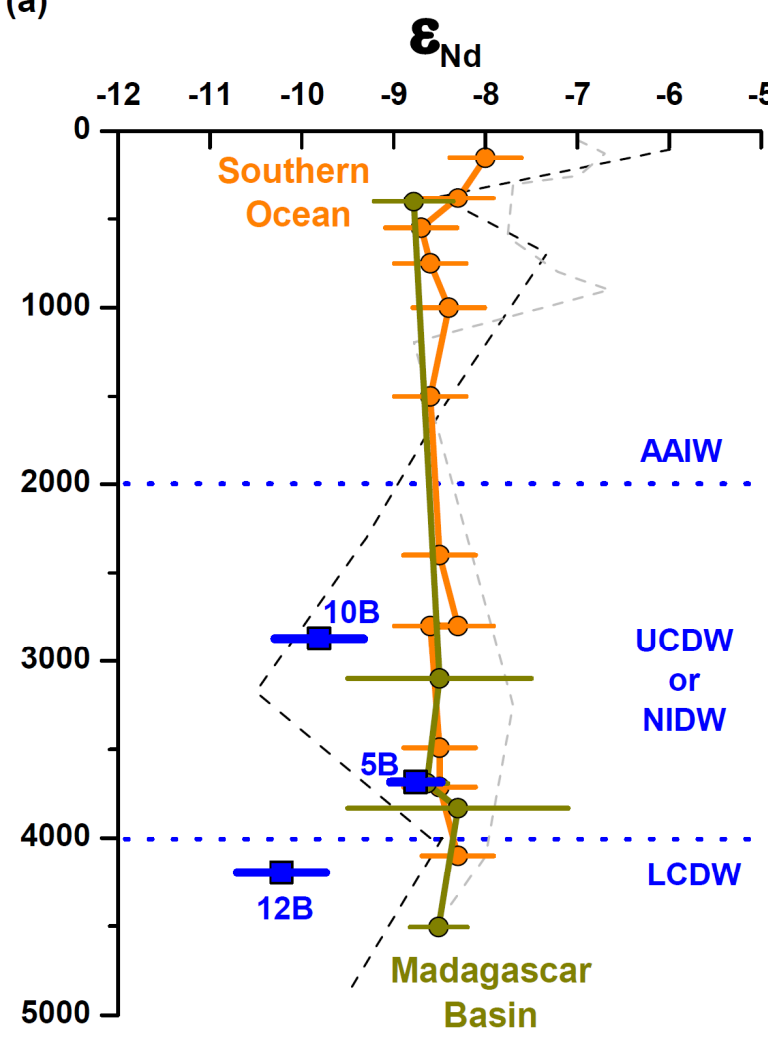

Depth (metres) (b)

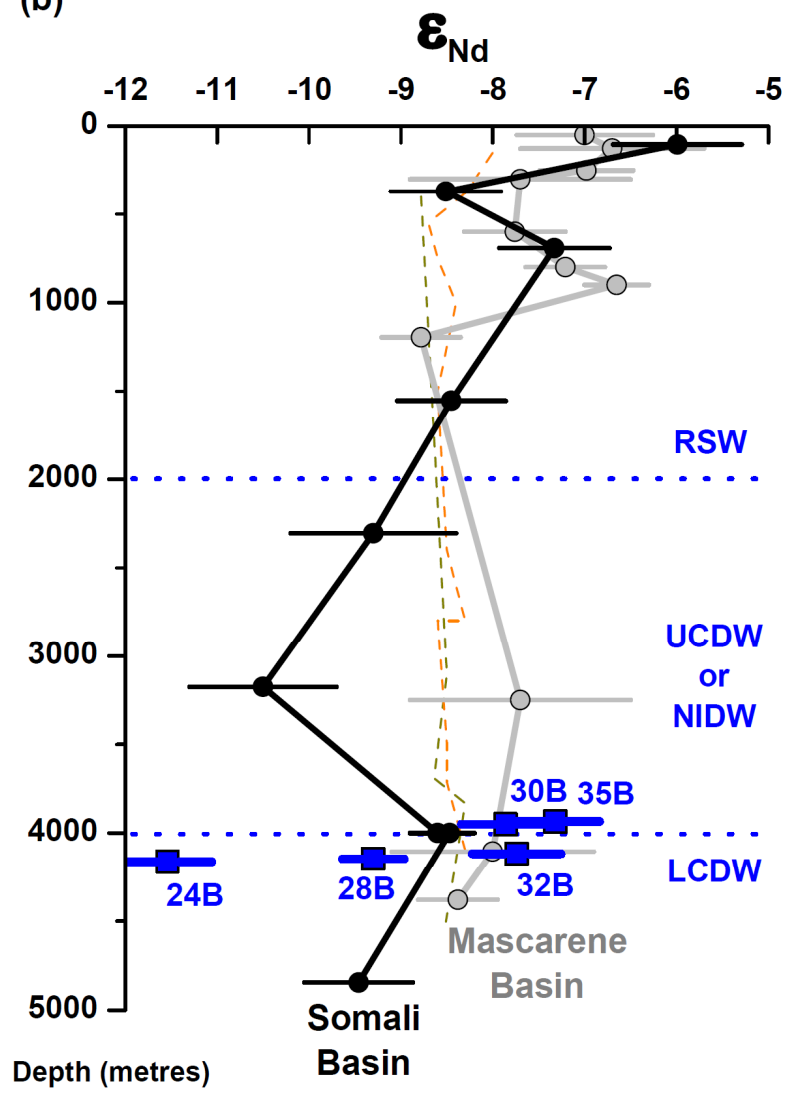

Figure 5: Holocene coretop $\varepsilon_{\mathrm{Nd}}$ from uncleaned foraminifera in the WIND cores (blue squares and labels) compared to open ocean seawater $\varepsilon_{\mathrm{Nd}}$ profiles. Plot (a) compares foraminifera data from the southern cores (WIND 5B, 10B and 12B) to water profiles from the Southern Ocean (a composite of Atlantic sector Station 113 for 0-2400 m and Drake Passage Stations 236, 241 and 244 for 2500-4100 m; Stichel et al., 2012; orange) and Madagascar Basin (CD1504/CD1505; Bertram and Elderfield, 1993; green). Plot (b) compares foraminifera data from the northern cores (WIND 24B, 28B, 30B, 32B and 35B) to water profiles from the Mascarene Basin (CD1502/CD1503; Bertram and Elderfield, 1993; grey) and Somali Basin (CD1506/CD1507; Bertram and Elderfield, 1993; black). In each case, water profiles from the other panel are shown with fine dotted lines to facilitate comparison. The locations of the western Indian Ocean profiles (Bertram and Elderfield, 1993) are shown in Figure 1. Blue lines and labels show the western Indian Ocean water column structure (McCave et al., 2005). Error bars on the data points represent $2 \sigma$. 


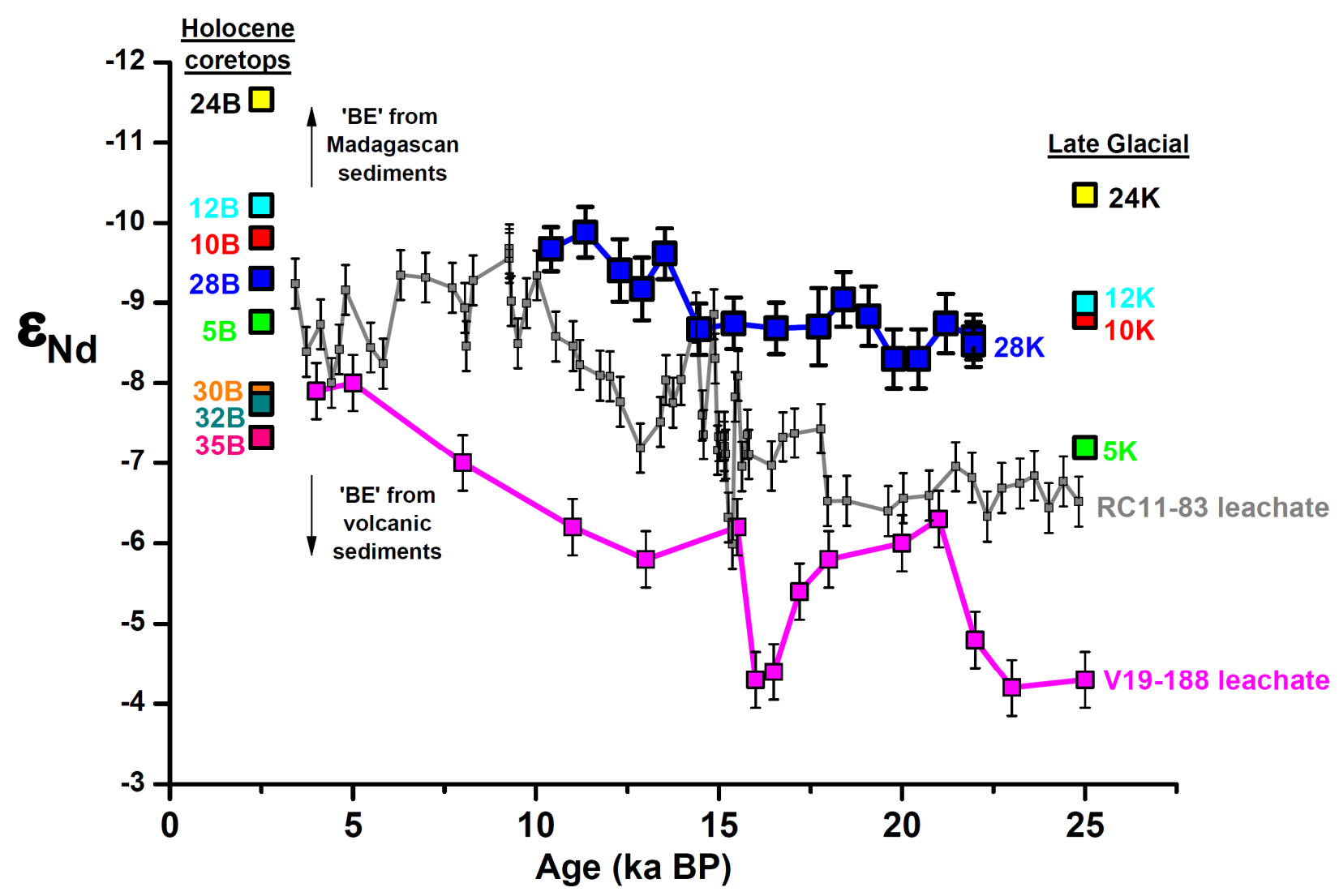

Figure 6: WIND $28 \mathrm{~K}$ uncleaned foraminifera $\varepsilon_{\mathrm{Nd}}$ record compared to sediment leachate $\varepsilon_{\mathrm{Nd}}$ records from RC11-83 (Piotrowski et al., 2005) and V19-188 (Pahnke et al., 2008). The RC11-83 and V19-188 records are plotted on their original published age models, with representative error bars ( $2 \sigma$ external) from those studies, while the age model for WIND $28 \mathrm{~K}$ is from $\mathrm{Yu}$ et al. (2010), after Kiefer et al. (2006). Also shown are uncleaned foraminifera $\varepsilon_{\mathrm{Nd}}$ data from the Holocene and Late Glacial WIND transects; for clarity these are plotted schematically as squares at $2.5 \mathrm{ka} \mathrm{BP}$ and $25 \mathrm{ka} \mathrm{BP}$ and error bars are not shown (but would be similar to the error bars on the WIND $28 \mathrm{~K}$ deglacial record). The directions of inferred boundary exchange ('BE') from Madagascan sediments and from volcanic sediments are shown with arrows. Note the reversed y axis scale for the $\varepsilon_{\mathrm{Nd}}$ data. 
Table 1: Details of WIND cores, with radiocarbon ages and carbonate contents for coretop $(0-2 \mathrm{~cm})$ samples.

\begin{tabular}{|c|c|c|c|c|c|}
\hline Core & $\begin{array}{l}\text { Latitude } \\
\left({ }^{\circ} \mathrm{S}\right)\end{array}$ & $\begin{array}{l}\text { Longitude } \\
\left.\text { ( }{ }^{\circ} \mathrm{E}\right)\end{array}$ & $\begin{array}{l}\text { Water depth } \\
\text { (m.b.s.l.) }\end{array}$ & $\begin{array}{c}\text { Coretop }{ }^{14} \mathrm{C} \text { age }{ }^{\mathrm{a}} \\
\text { (yr } \pm \text { error })\end{array}$ & $\begin{array}{c}\text { Carbonate }^{\mathrm{b}} \\
(\%)\end{array}$ \\
\hline $5 B$ & $31^{\circ} 34.14^{\prime}$ & $47^{\circ} 34.15^{\prime}$ & 3684 & $5447 \pm 22$ & 86 \\
\hline 10B & $29^{\circ} 07.49^{\prime}$ & $47^{\circ} 32.94^{\prime}$ & 2871 & $7252 \pm 27$ & 83 \\
\hline 12B & $25^{\circ} 50.79^{\prime}$ & $47^{\circ} 55.37^{\prime}$ & 4196 & $7113 \pm 29$ & 40 \\
\hline 24B & $13^{\circ} 04.45^{\prime}$ & $51^{\circ} 20.01^{\prime}$ & 4163 & $4167 \pm 27$ & 25 \\
\hline 28B & $10^{\circ} 09.33^{\prime}$ & $51^{\circ} 46.22^{\prime}$ & 4147 & $5484 \pm 39$ & 43 \\
\hline $30 \mathrm{~B}$ & $07^{\circ} 58.69^{\prime}$ & $52^{\circ} 07.00^{\prime}$ & 3950 & $6456 \pm 28$ & 75 \\
\hline 32B & $11^{\circ} 14.19^{\prime}$ & $58^{\circ} 13.18^{\prime}$ & 4117 & $4663 \pm 25$ & 80 \\
\hline 35B & $16^{\circ} 25.33^{\prime}$ & $58^{\circ} 03.94^{\prime}$ & 3934 & $3807 \pm 26$ & 89 \\
\hline
\end{tabular}

Notes:

a: Radiocarbon ages are from $G$. sacculifer. No reservoir age correction or calendar year calibration has been applied.

b: For weight percent calcium carbonate determination, bulk sediment samples were acidified using an AutoMateFX carbonate preparation system and evolved $\mathrm{CO}_{2}$ was measured using a UIC (Coulometrics) 5012 $\mathrm{CO}_{2}$ coulometer. Analytical precision is estimated to be $\pm 1 \%$ by measurement of a pure carbonate standard.

Table 2: $\mathrm{Nd}$ isotope data for Holocene coretop samples $(0-2 \mathrm{~cm}$ core depth).

\begin{tabular}{|c|c|c|c|c|c|c|c|c|c|}
\hline \multirow{2}{*}{ Core } & \multicolumn{3}{|c|}{$\begin{array}{c}\text { Decarbonated HH } \\
\text { leachates }\end{array}$} & \multicolumn{2}{|c|}{$\begin{array}{c}\text { Non- } \\
\text { decarbonated } \\
\text { HH leachates }\end{array}$} & \multicolumn{2}{|c|}{$\begin{array}{l}\text { Uncleaned } \\
\text { foraminifera }\end{array}$} & \multicolumn{2}{|c|}{ Detrital residue } \\
\hline & $\begin{array}{c}\text { Weight } \\
\text { (g) }\end{array}$ & $\varepsilon_{\mathrm{Nd}}{ }^{b}$ & $2 \sigma^{c}$ & $\varepsilon_{\mathrm{Nd}}{ }^{\mathrm{b}}$ & $2 \sigma^{c}$ & $\varepsilon_{\mathrm{Nd}}{ }^{\mathrm{b}}$ & $2 \sigma^{c}$ & $\varepsilon_{\mathrm{Nd}}{ }^{b}$ & $2 \sigma^{c}$ \\
\hline $5 B$ & 1.7 & -8.32 & 0.29 & - & - & -8.76 & 0.27 & -11.69 & 0.25 \\
\hline 10B & 1.9 & -9.35 & 0.29 & - & - & -9.81 & 0.48 & -18.33 & 0.25 \\
\hline 12B & 7.0 & -9.84 & 0.29 & - & - & -10.22 & 0.48 & -18.18 & 0.25 \\
\hline 24B & 9.4 & -10.98 & 0.29 & -11.20 & 0.13 & -11.54 & 0.48 & -15.40 & 0.25 \\
\hline 28B & 7.9 & -9.62 & 0.29 & -9.75 & 0.13 & -9.30 & 0.34 & -14.17 & 0.35 \\
\hline 30B & 4.2 & -8.38 & 0.29 & - & - & -7.86 & 0.48 & -12.05 & 0.25 \\
\hline 32B & 5.4 & -7.32 & 0.29 & - & - & -7.74 & 0.48 & -9.80 & 0.35 \\
\hline 35B & 1.9 & -7.28 & 0.29 & - & - & -7.32 & 0.48 & -9.36 & 0.49 \\
\hline
\end{tabular}

\section{Notes:}

a: Weight $(\mathrm{g})=$ wet weight in grams of bulk sediment leached (after decarbonation).

b: All Nd isotope data are corrected to the JNdi-1 neodymium isotope standard which has ${ }^{143} \mathrm{Nd} /{ }^{144} \mathrm{Nd}=$ 0.512115 (Tanaka et al., 2000).

c: Data were collected in a number of different analytical sessions and measurement errors are taken from the within-session standard deviation $(2 \sigma)$ on concentration-matched JNdi-1 standards (unless the internal error is larger). Some samples (typically foraminifera) were analysed at lower than optimal concentrations due to sample limitation, with a consequently larger $2 \sigma$ on the concentration-matched standards. For samples analysed in duplicate, the reported $\varepsilon_{\mathrm{Nd}}$ values are the mean, weighted according to the variance, and the $2 \sigma$ standard error. 
Table 3: Nd isotope data for Late Glacial and deglacial samples.

\begin{tabular}{|c|c|c|c|c|c|c|c|c|c|c|c|c|}
\hline \multirow{2}{*}{ Core } & \multicolumn{4}{|c|}{ Uncleaned foraminifera } & \multicolumn{4}{|c|}{$\begin{array}{c}\begin{array}{c}\text { Non-decarbonated HH } \\
\text { leachates }\end{array} \\
\end{array}$} & \multicolumn{4}{|c|}{ Detrital residue } \\
\hline & Depth $^{a}$ & $\mathrm{Age}^{\mathrm{b}}$ & $\varepsilon_{\mathrm{Nd}}{ }^{\mathrm{c}}$ & $2 \sigma^{d}$ & Depth & Age & $\varepsilon_{\mathrm{Nd}}^{\mathrm{c}}$ & $2 \sigma^{d}$ & Depth & Age & $\varepsilon_{\mathrm{Nd}}^{\mathrm{c}}$ & $2 \sigma^{d}$ \\
\hline $5 K$ & $18-19$ & LG & $\begin{array}{l}-7.19 \\
\end{array}$ & 0.28 & 17-18 & LG & -6.95 & 0.15 & - & - & - & - \\
\hline $10 \mathrm{~K}$ & $18-19$ & $\mathrm{LG}$ & -8.82 & 0.28 & $19-20$ & LG & -8.85 & 0.15 & - & - & - & - \\
\hline $12 \mathrm{~K}$ & $48-49$ & LG & -8.99 & 0.39 & $49-50$ & LG & -8.84 & 0.49 & - & - & - & - \\
\hline $24 K$ & $50-51$ & LG & -10.35 & 0.35 & $50-51$ & LG & -10.45 & 0.25 & - & - & - & - \\
\hline $28 \mathrm{~K}$ & $32-33$ & 10.41 & -9.67 & 0.28 & - & - & - & - & - & - & - & - \\
\hline $28 \mathrm{~K}$ & $36-37$ & 11.35 & -9.88 & 0.32 & - & - & - & - & - & - & - & - \\
\hline $28 \mathrm{~K}$ & $40-41$ & 12.29 & -9.40 & 0.39 & - & - & - & - & - & - & - & - \\
\hline $28 \mathrm{~K}$ & - & - & - & - & $42-43$ & 12.60 & -9.50 & 0.15 & - & - & - & - \\
\hline $28 \mathrm{~K}$ & $44-45$ & 12.90 & -9.17 & 0.39 & - & - & - & - & - & - & - & - \\
\hline $28 \mathrm{~K}$ & $48-49$ & 13.52 & -9.61 & 0.32 & - & - & - & - & - & - & - & - \\
\hline $28 \mathrm{~K}$ & $52-53$ & 14.46 & -8.67 & 0.32 & - & - & - & - & - & - & - & - \\
\hline $28 \mathrm{~K}$ & $56-57$ & 15.40 & -8.74 & 0.32 & - & - & - & - & - & - & - & - \\
\hline $28 \mathrm{~K}$ & $60-61$ & 16.56 & -8.68 & 0.32 & - & - & - & - & - & - & - & - \\
\hline $28 \mathrm{~K}$ & - & - & - & - & $62-63$ & 17.14 & -8.71 & 0.15 & - & - & - & - \\
\hline $28 \mathrm{~K}$ & $64-65$ & 17.72 & -8.70 & 0.48 & - & - & - & - & - & - & - & - \\
\hline $28 \mathrm{~K}$ & $68-69$ & 18.40 & -9.04 & 0.34 & - & - & - & - & - & - & - & - \\
\hline $28 \mathrm{~K}$ & $72-73$ & 19.09 & -8.83 & 0.37 & - & - & - & - & - & - & - & - \\
\hline $28 \mathrm{~K}$ & $76-77$ & 19.77 & -8.30 & 0.37 & - & - & - & - & - & - & - & - \\
\hline $28 \mathrm{~K}$ & $80-81$ & 20.45 & -8.30 & 0.37 & - & - & - & - & $80-81$ & 20.45 & -14.71 & 0.25 \\
\hline $28 \mathrm{~K}$ & - & - & - & - & $82-83$ & 20.82 & -8.50 & 0.15 & - & - & - & - \\
\hline $28 \mathrm{~K}$ & $84-85$ & 21.20 & -8.74 & 0.37 & - & - & - & - & - & - & - & - \\
\hline $28 \mathrm{~K}$ & $88-89$ & 21.95 & -8.57 & 0.28 & - & - & - & - & - & - & - & - \\
\hline $28 \mathrm{~K}$ & $88-89$ & 21.95 & $-8.48^{\mathrm{e}}$ & 0.28 & - & - & - & - & - & - & - & - \\
\hline
\end{tabular}

Notes:

a: Depth = core depth in $\mathrm{cm}$.

b: Age = age in ka BP; ages for WIND 28K are from Yu et al. (2010) after Kiefer et al. (2006); LG = Late

Glacial (see text).

c: All Nd isotope data are corrected to the JNdi-1 neodymium isotope standard which has ${ }^{143} \mathrm{Nd} /{ }^{144} \mathrm{Nd}=$

0.512115 (Tanaka et al., 2000).

$\mathrm{d}$ : Data were collected in a number of different analytical sessions and measurement errors are taken from the within-session standard deviation $(2 \sigma)$ on concentration-matched JNdi-1 standards (unless the internal error is larger). Some samples (typically foraminifera) were analysed at lower than optimal concentrations due to sample limitation, with a consequently larger $2 \sigma$ on the concentration-matched standards. For samples analysed in duplicate, the reported $\varepsilon_{\mathrm{Nd}}$ values are the mean, weighted according to the variance, and the $2 \sigma$ standard error. e: Foraminifera dissolution in $1 \mathrm{M}$ nitric acid instead of acetic acid.

Table 4: A simple boundary exchange model.

\begin{tabular}{|c|c|c|c|c|c|}
\hline & $\begin{array}{c}\text { Inflow site } \\
\text { foraminifera } \\
\text { (WIND 5B/K) }\end{array}$ & $\begin{array}{c}\text { Madagascan } \\
\text { margin } \\
\text { sediments }\end{array}$ & $\begin{array}{c}\text { Margin site } \\
\text { foraminifera } \\
\text { (WIND 24B/K) }\end{array}$ & $\Delta$ spatial $^{\mathrm{e}}$ & $\begin{array}{l}\text { \% boundary } \\
\text { exchange }\end{array}$ \\
\hline Holocene & $-8.8^{a}$ & $-18.3^{b}$ & $-11.5^{\mathrm{a}}$ & 2.8 & $\geq 29 \%$ \\
\hline Late Glacial & $-7.2^{a}$ & $-18.3^{c}$ & $-10.4^{a}$ & 3.2 & $\geq 29 \%$ \\
\hline$\Delta$ temporal $^{\mathrm{d}}$ & 1.6 & $0^{c}$ & 1.2 & & \\
\hline
\end{tabular}

\section{Notes:}

a: Measured $\varepsilon_{\mathrm{Nd}}$ values from uncleaned foraminifera.

b: Average of Holocene detrital sediment $\varepsilon_{\mathrm{Nd}}$ values at WIND 10B and WIND 12B.

c: The Late Glacial detrital sediment $\varepsilon_{\mathrm{Nd}}$ values at WIND $10 \mathrm{~K}$ and WIND $12 \mathrm{~K}$ are assumed to match the Holocene values, which is unproven at these sites but is demonstrated at WIND 28K.

$\mathrm{d}$ : $\Delta$ temporal reports the glacial-interglacial $\varepsilon_{\mathrm{Nd}}$ changes at each site.

e: $\Delta$ spatial reports the along-margin $\varepsilon_{\mathrm{Nd}}$ gradient for the Holocene and Late Glacial.

$\mathrm{f}$ : \% boundary exchange indicates the proportion of the $\mathrm{Nd}$ at the margin site that is required to derive from boundary addition; this represents a minimum since it makes no allowance for $\mathrm{Nd}$ removal along the margin. 


\section{Supplementary information}

This section provides information on the Late Glacial sampling of cores WIND 12K and WIND 24K. This was based on correlation of the magnetic susceptibility records from these cores to the magnetic susceptibility record from nearby core WIND 28K (Supplementary Figure S1).

Additionally, for a WIND $12 \mathrm{~K}$ sample at $48-49 \mathrm{~cm}$ depth, benthic foraminiferal (Cibicidoides wuellerstorfi, $>212 \mu \mathrm{m}) \delta^{18} \mathrm{O}$ and $\delta^{13} \mathrm{C}$ were measured in the Godwin Laboratory $\left(\delta^{18} \mathrm{O}=4.20 \%\right.$ VPDB, $\delta^{13} \mathrm{C}=0.36 \%$ VPDB). Foraminifera (typically 3 to 5 specimens) were transferred into sample vials, crushed and soaked in a solution of $3 \%$ hydrogen peroxide for 30 minutes before being removed. After an acetone ultrasonic bath, the samples were dried at $50{ }^{\circ} \mathrm{C}$ overnight. The samples were analyzed using a Micromass Multicarb Sample Preparation System attached to a VG SIRA mass spectrometer or a VG PRISM mass spectrometer. Each run of 30 samples was accompanied by 10 reference carbonates and 2 control samples. The results are reported with reference to the international standard Vienna PeeDee Belemnite (VPDB) and the precision is better than $\pm 0.06 \%$ for ${ }^{13} \mathrm{C} /{ }^{12} \mathrm{C}$ and $\pm 0.08 \%$ o for ${ }^{18} \mathrm{O} /{ }^{16} \mathrm{O}$. 


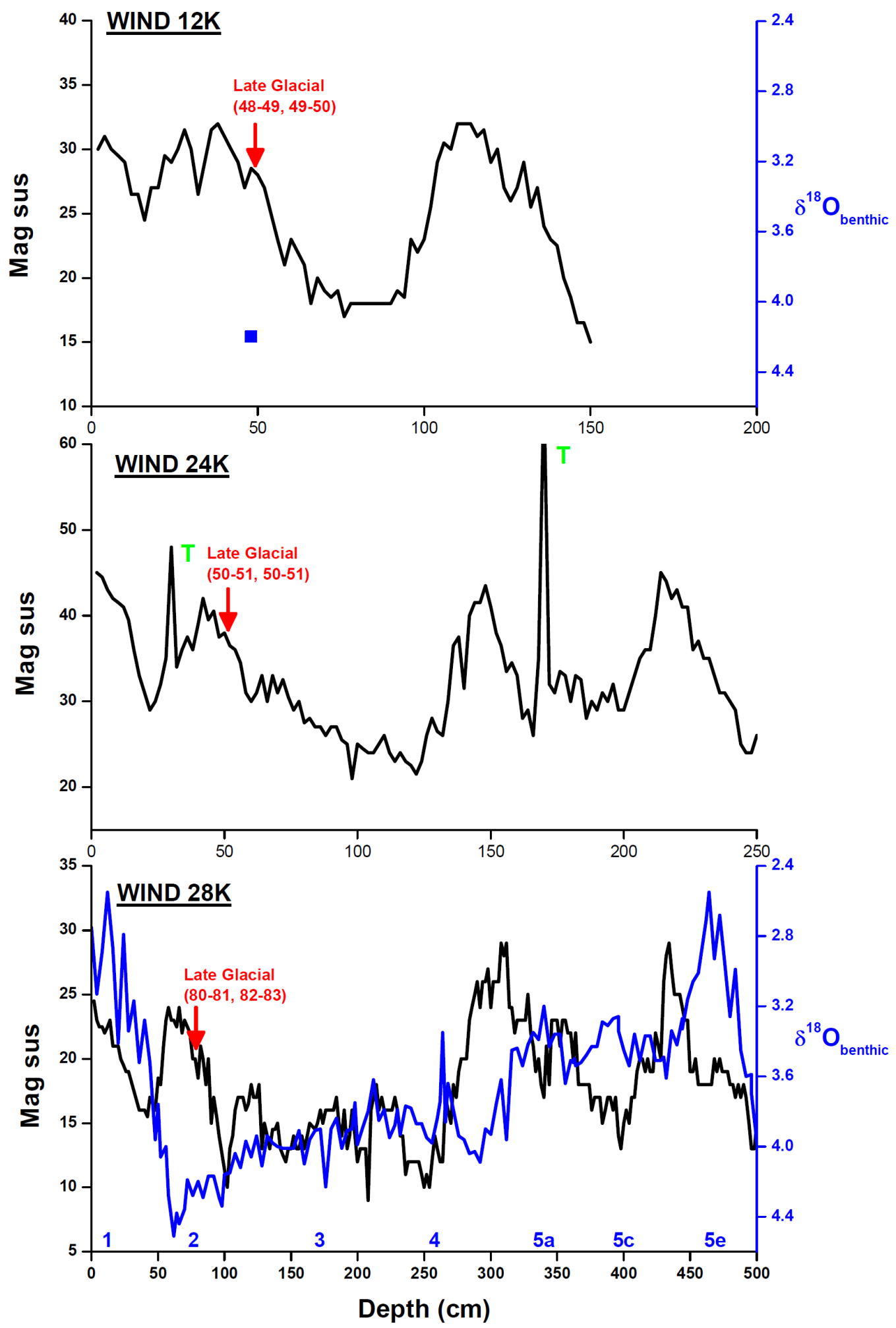

Supplementary Figure S1: Sampling of WIND 12K and WIND 24K in the Late Glacial determined by correlation of their magnetic susceptibility records to magnetic susceptibility record from well dated nearby core WIND 28K. The above plots show magnetic susceptibility records from the three cores, measured at $2 \mathrm{~cm}$ intervals with a Bartington point probe. All data is plotted on depth scales and approximately aligned; therefore, note the differing $\mathrm{x}$ axis scales in each case. Also shown is the benthic $\delta^{18} \mathrm{O}(C$. wuellerstorfi) record from WIND 28K (McCave et al., 2005) labelled with marine isotope stage numbers, and one measurement of benthic $\delta^{18} \mathrm{O}$ (C. wuellerstorfi) from WIND $12 \mathrm{~K}$ (this study). Red arrows on each plot represent Late Glacial sampling, with two numbers in brackets giving sample depths of 'uncleaned' foraminifera and non-decarbonated HH leachates, respectively (see Table 3). Two anomalous magnetic susceptibility peaks in core WIND $24 \mathrm{~K}$ are labelled with $\mathrm{T}$, representing turbidites. 